\title{
U.S. Geological Survey Groundwater Toolbox, A Graphical and Mapping Interface for Analysis of Hydrologic Data (Version 1.0) - User Guide for Estimation of Base Flow, Runoff, and Groundwater Recharge From Streamflow Data
}

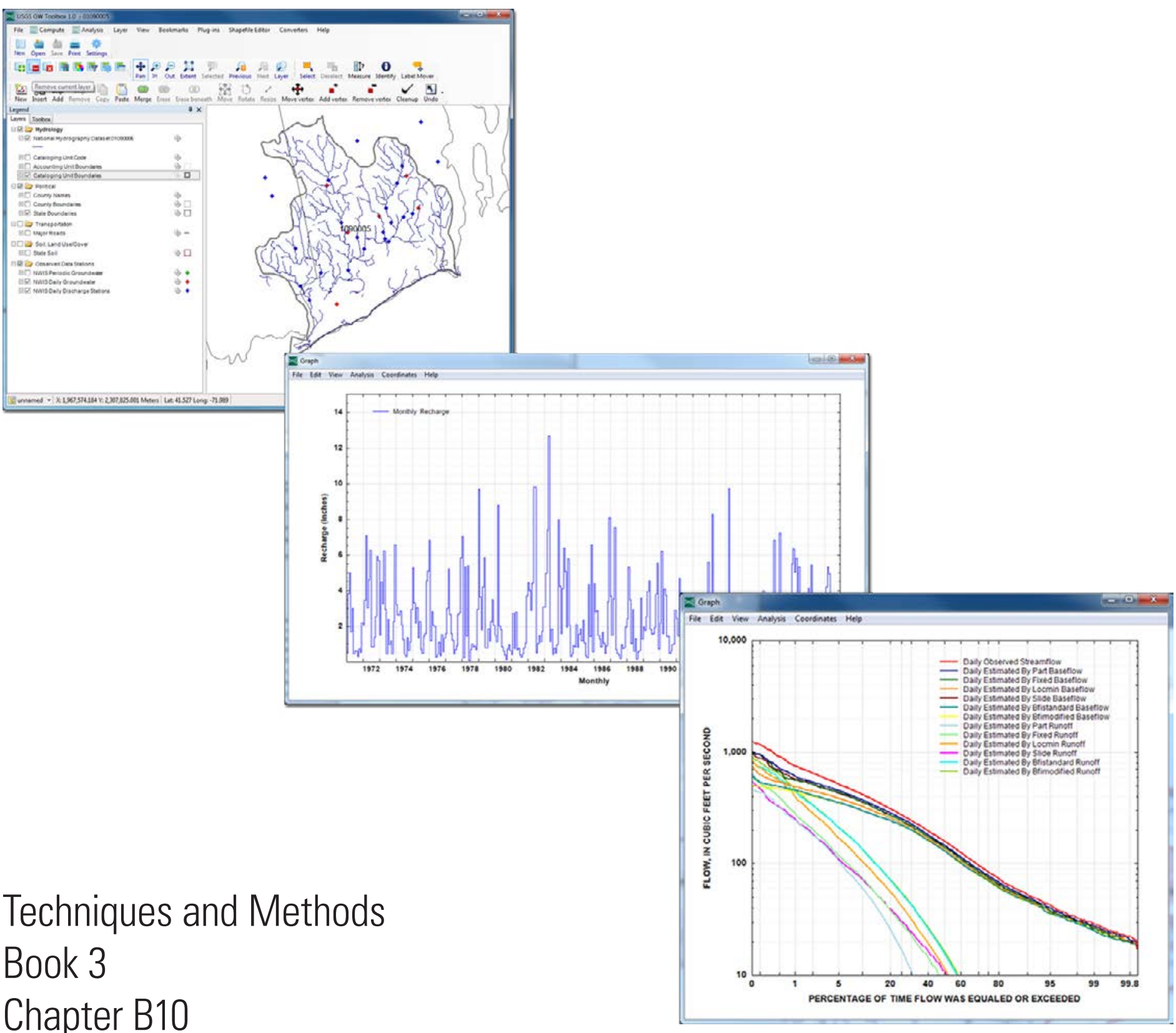

U.S. Department of the Interior

U.S. Geological Survey 
Cover. Screen captures of the U.S. Geological Survey Groundwater Toolbox showing a map of streamflow and groundwater-level datacollection locations (top), estimated monthly recharge (middle), and flow-duration curves for measured streamflow and estimated base flow and runoff (bottom) for the Pawcatuck River Basin at Wood River Junction, Rhode Island, streamgage. 


\section{U.S. Geological Survey Ground water Toolbox, A Graphical and Mapping Interface for Analysis of Hydrologic Data (Version 1.0)—User Guide for Estimation of Base Flow, Runoff, and Groundwater Recharge From Streamflow Data}

By Paul M. Barlow, William L. Cunningham, Tong Zhai, and Mark Gray

Techniques and Methods

Book 3

Chapter B10 


\title{
U.S. Department of the Interior SALLY JEWELL, Secretary
}

\section{U.S. Geological Survey \\ Suzette M. Kimball, Acting Director}

\author{
U.S. Geological Survey, Reston, Virginia: 2015
}

For more information on the USGS - the Federal source for science about the Earth, its natural and living resources, natural hazards, and the environment, visit http://www.usgs.gov/ or call 1-888-ASK-USGS.

For an overview of USGS information products, including maps, imagery, and publications, visit http://www.usgs.gov/pubprod/

To order this and other USGS information products, visit http://store.usgs.gov/

Any use of trade, firm, or product names is for descriptive purposes only and does not imply endorsement by the U.S. Government.

Although this information product, for the most part, is in the public domain, it also may contain copyrighted materials as noted in the text. Permission to reproduce copyrighted items must be secured from the copyright owner.

Suggested citation:

Barlow, P.M., Cunningham, W.L., Zhai, Tong, and Gray, Mark, 2015, U.S. Geological Survey Groundwater Toolbox, a graphical and mapping interface for analysis of hydrologic data (version 1.0)—User guide for estimation of base flow, runoff, and groundwater recharge from streamflow data: U.S. Geological Survey Techniques and Methods, book 3, chap. B10, 27 p., http://dx.doi.org/10.3133/tm3B10. 


\section{Preface}

This report is a user guide for the streamflow-hydrograph analysis methods provided with version 1.0 of the U.S. Geological Survey Groundwater Toolbox. These include six hydrograph-separation methods to determine the groundwater-discharge (base-flow) and surface-runoff components of streamflow-the Base-Flow Index (BFl; Standard and Modified), HYSEP (Fixed Interval, Sliding Interval, and Local Minimum), and PART hydrograph-separation methods - and the RORA recession-curve displacement method and supporting RECESS program to estimate groundwater recharge from streamflow data. The performance of the program has been tested in a variety of applications, some of which are documented in this report. Future applications, however, might reveal errors that were not detected in the test simulations. Users are requested to notify the U.S. Geological Survey (USGS) of any errors found in this report or the computer program.

Although this computer program has been written and used by the USGS, no warranty, expressed or implied, is made by the USGS or the U.S. Government as to the accuracy and functionality of the program and related program material, nor shall the fact of distribution constitute any such warranty, and no responsibility is assumed by the USGS in connection therewith. The Groundwater Toolbox and other groundwater programs are available online from the USGS at http://water.usgs.gov/software/lists/groundwater/. Information on how to download and install the program can be found at that Web site. 


\section{Acknowledgments}

We thank our U.S. Geological Survey (USGS) colleagues David Nelms and Richard Healy for their review of the Groundwater (GW) Toolbox and an earlier draft of this report. We also thank Leslie DeSimone and Anna Glover, USGS, for their editorial comments on the draft report. David Nelms and Ronald Sloto of the USGS and Tony Wahl of the Bureau of Reclamation did extensive testing of successive draft versions of the GW Toolbox; their reviews identified errors in the implementation of the hydrograph-analysis methods in the GW Toolbox that could be corrected before release of the code. Albert Rutledge, USGS (retired), also provided several helpful review comments on the PART, RORA, and RECESS programs described in this report. We also thank several other of our USGS colleagues who tested the GW Toolbox and provided feedback on the software. 


\section{Contents}

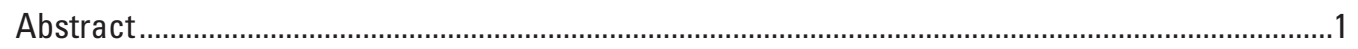

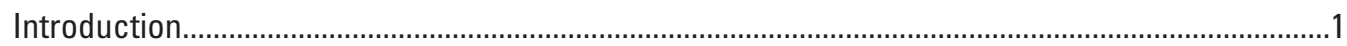

Base-Flow, Runoff, and Recharge Estimation Methods and Applicability................................2

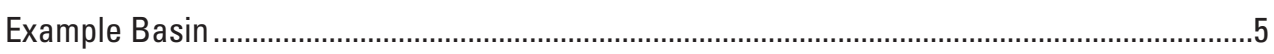

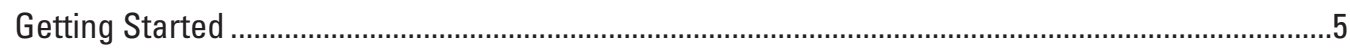

Building, Saving, and Reopening a Project ........................................................................

Time-Series Data Discovery and Retrieval......................................................................

Summarizing, Listing, and Graphing Time-Series Data .......................................................11

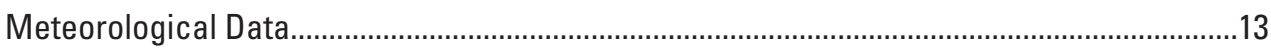

Base-Flow and Runoff Components of Streamflow: Hydrograph Separation .................................16

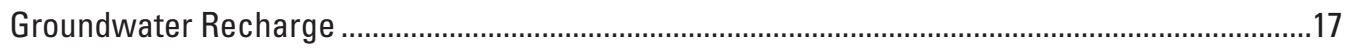

RECESS Program To Estimate Basin Recession Index.........................................................17

RORA Program To Estimate Groundwater Recharge.........................................................21

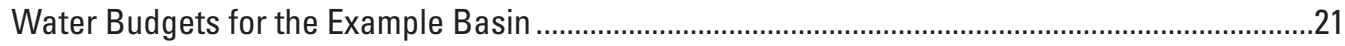

Summary

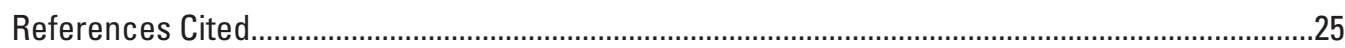

\section{Figures}

1. Guidance on appropriateness of hydrograph-analysis methods provided with the Groundwater Toolbox.

2. Screen captures showing the "Welcome to the USGS GW Toolbox 1.0" and "USGS GW Toolbox 1.0" dialog boxes that appear on first use of the Groundwater Toolbox ......6

3. Screen captures showing the initial map with data layers active that show states and hydrologic cataloging units.

4. Screen captures showing the method for adding labels to a map layer. In this example, cataloging-unit numbers are added to the Cataloging Units layer. A, Options available by right-clicking on the selected layer, "Cataloging Units." B, "Label-style" dialog box that appears after selecting the "Label Setup" option, and, C, The resulting map, with cataloging-unit labels added.

5. Screen captures showing selected steps to build a Groundwater Toolbox project. A, The "Select" tool is used to select the cataloging unit (basin) of interest, which is then shaded yellow. B, The resulting map, which includes daily streamflow (discharge) and groundwater-level data-collection locations for the basin of interest and surrounding area.

6. Screen capture showing steps used to select one or more data sites for which data can be retrieved from the U.S. Geological Survey National Water Information System for use in the Groundwater Toolbox.

7. Screen captures showing dialog boxes used to retrieve data from the U.S. Geological Survey National Water Information System and other sources for use in the Groundwater Toolbox. A, The "Download Data" dialog box used to retrieve streamflow (discharge) data. B, The dialog box indicating that the data for the site of interest (01117500) have been retrieved and are available for use. 
8. Screen captures showing dialog boxes used to select and graph data for use in the Groundwater Toolbox. A, The "Select Data to Graph" dialog box for selecting time-series data to graph. B, The "Choose Graphs to Create" dialog box to select graph types.

9. Screen captures showing graphs of streamflow data at the example streamgage on the Pawcatuck River at Wood River Junction, Rhode Island, for use in the Groundwater Toolbox. A, Streamflow hydrograph. B, Flow-duration curve

10. Screen captures showing dialog boxes used in the base-flow separation analysis component of the Groundwater Toolbox. A, The "Base-Flow Separation" dialog box. B, Part of the "Data Summary" dialog box, which shows months having complete (dots) or incomplete (Xs) records

11. Screen capture showing the flow-duration curves for measured streamflow and estimated base flow and runoff for the Pawcatuck River at Wood River Junction, Rhode Island, from 1971 through 2000 using the six hydrograph-separation methods available in the Groundwater Toolbox

12. Screen captures showing dialog boxes used for the RECESS component of the Groundwater Toolbox. A, Initial dialog box to specify the dates, months, and seasons for analysis, the minimum number of days required for detection of a recession period, and the output directory. B, Dialog box showing recession periods that meet the minimum-day requirement (left side of dialog box), the first recession period beginning after a peak streamflow on January 7, 1971 (middle part of dialog box), and a semilogarithmic graph of the first recession period (right side of dialog box). C, Dialog box showing the estimated recession index of 38.432305 days per log cycle for full period of recession from January 8 through January 22, 1971, D, The "Choose Recession Limb Duration" dialog box allows the user to refine the days that will be used to calculate the recession index. E, Dialog box showing a summary, the median value, and a scatter plot of the recession indices calculated by RECESS for the example basin.

13. Screen capture showing the "USGS RORA" dialog box to estimate groundwater recharge by use of the RORA program in the Groundwater Toolbox.

14. Screen capture showing graph of monthly recharge, in inches over the drainage basin, calculated by the RORA program for the Pawcatuck River Basin at Wood River Junction, Rhode Island, from January 1971 through December 2000.

\section{Table}

1. Water-budget components estimated for the Pawcatuck River Basin at Wood River Junction, Rhode Island from 1971 through 2000 


\section{Conversion Factors}

Inch/Pound to International System of Units

\begin{tabular}{lll}
\hline \multicolumn{1}{c}{ Multiply } & \multicolumn{1}{c}{ By } & \multicolumn{1}{c}{ To obtain } \\
\hline cubic foot per second $\left(\mathrm{ft}^{3} / \mathrm{s}\right)$ & 0.02832 & cubic meter per second $\left(\mathrm{m}^{3} / \mathrm{s}\right)$ \\
foot $(\mathrm{ft})$ & 0.3048 & meter $(\mathrm{m})$ \\
inch (in.) & 2.54 & centimeter $(\mathrm{cm})$ \\
inch per year $(\mathrm{in} / \mathrm{yr})$ & 2.54 & centimeter per year $(\mathrm{cm} / \mathrm{yr})$ \\
square mile $\left(\mathrm{mi}^{2}\right)$ & 2.590 & square kilometer $\left(\mathrm{km}^{2}\right)$ \\
\hline
\end{tabular}

Temperature in degrees Celsius $\left({ }^{\circ} \mathrm{C}\right)$ may be converted to degrees Fahrenheit $\left({ }^{\circ} \mathrm{F}\right)$ as ${ }^{\circ} \mathrm{F}=(1.8 \times$ $\left.{ }^{\circ} \mathrm{C}\right)+32$.

Temperature in degrees Fahrenheit $\left({ }^{\circ} \mathrm{F}\right)$ may be converted to degrees Celsius $\left({ }^{\circ} \mathrm{C}\right)$ as ${ }^{\circ} \mathrm{C}=\left({ }^{\circ} \mathrm{F}-\right.$ 32) / 1.8 .

\section{Abbreviations}

$\begin{array}{ll}\text { BASINS } & \begin{array}{l}\text { Better Assessment Science Integrating Point and Nonpoint Sources } \\ \text { environmental analysis system }\end{array} \\ \text { BFI } & \text { Base-Flow Index method } \\ \text { EPA } & \text { U.S. Environmental Protection Agency } \\ \text { GIS } & \text { geographic information system } \\ \text { GW } & \text { groundwater } \\ \text { NOAA } & \text { National Oceanic and Atmospheric Administration } \\ \text { NCDC } & \text { National Climatic Data Center } \\ \text { NWIS } & \text { National Water Information System } \\ \text { USGS } & \text { U.S. Geological Survey }\end{array}$





\title{
U.S. Geological Survey Groundwater Toolbox, A Graphical and Mapping Interface for Analysis of Hydrologic Data (Version 1.0)—User Guide for Estimation of Base Flow, Runoff, and Groundwater Recharge From Streamflow Data
}

\author{
By Paul M. Barlow, ${ }^{1}$ William L. Cunningham, ${ }^{1}$ Tong Zhai, ${ }^{2}$ and Mark Gray ${ }^{2}$
}

\section{Abstract}

This report is a user guide for the streamflow-hydrograph analysis methods provided with version 1.0 of the U.S. Geological Survey (USGS) Groundwater Toolbox computer program. These include six hydrograph-separation methods to determine the groundwater-discharge (base-flow) and surfacerunoff components of streamflow-the Base-Flow Index (BFI; Standard and Modified), HYSEP (Fixed Interval, Sliding Interval, and Local Minimum), and PART methods - and the RORA recession-curve displacement method and associated RECESS program to estimate groundwater recharge from streamflow data. The Groundwater Toolbox is a customized interface built on the nonproprietary, open source MapWindow geographic information system software. The program provides graphing, mapping, and analysis capabilities in a Microsoft Windows computing environment. In addition to the four hydrograph-analysis methods, the Groundwater Toolbox allows for the retrieval of hydrologic time-series data (streamflow, groundwater levels, and precipitation) from the USGS National Water Information System, downloading of a suite of preprocessed geographic information system coverages and meteorological data from the National Oceanic and Atmospheric Administration National Climatic Data Center, and analysis of data with several preprocessing and postprocessing utilities. With its data retrieval and analysis tools, the Groundwater Toolbox provides methods to estimate many of the components of the water budget for a hydrologic basin, including precipitation; streamflow; base flow; runoff; groundwater recharge; and total, groundwater, and near-surface evapotranspiration.

\footnotetext{
${ }^{1}$ U.S. Geological Survey

${ }^{2}$ AQUA TERRA Consultants
}

\section{Introduction}

Analysis of streamflow hydrographs has long been used to identify the groundwater-discharge (or base-flow) and surface-runoff components of streamflow, as well as to estimate basinwide rates of groundwater recharge. These analyses not only provide insight to the relative contributions of groundwater discharge and surface runoff to streams, but also help to quantify the groundwater components of basin-scale hydrologic budgets. Many hydrograph-separation methods have been developed to estimate the base-flow and runoff components of streamflow and, in recent years, these methods have been implemented in a number of computer programs that facilitate the estimation process (Nathan and McMahon, 1990; Wahl and Wahl, 1995; Sloto and Crouse, 1996; Rutledge, 1998; Arnold and Allen, 1999; Eckhardt, 2005; Lim and others, 2005; Piggott and others, 2005). Although each of the methods is based on formalized algorithms for identifying the base-flow component of total streamflow, the methods are subjective and not based on mathematical solutions to groundwater- or overland-flow equations. As a result, it is advantageous to use more than one hydrograph-separation method to analyze a streamflow record and then to compare the results of the multiple methods.

A method also has been developed to estimate groundwater recharge from streamflow hydrographs. Unlike the empirical hydrograph-separation methods, the recharge-estimation method, which is referred to as the recession-curve displacement method (Rorabaugh, 1964), is based on a mathematical solution to a one-dimensional form of the groundwater-flow equation for conditions of an instantaneous rise in the height of the water table over the basin.

Although several computer programs have been written for hydrograph separation and the estimation of groundwater recharge, the programs must be run individually and their results, which often are presented in different formats, compared manually. Moreover, each of the existing programs must be maintained and supported, and in some cases have become outdated and difficult to use. As a result, the U.S. 
Geological Survey (USGS) Office of Groundwater determined that it would be useful to develop a single program in which a suite of application tools, including data retrieval and multiple hydrograph-separation and recharge-estimation methods, would be available for use in a modern computing environment. The USGS collaborated under contract with AQUA TERRA Consultants to develop the Groundwater (GW) Toolbox, which is a customized interface built on the MapWindow geographic information system (GIS) software (MapWindow, 2013). MapWindow is a nonproprietary, open-source program that provides GIS capabilities in a graphical user interface and runs in a Microsoft Windows computing environment. The GW Toolbox has a similar interface and many of the same utilities as the Better Assessment Science Integrating Point and Non-point Sources (BASINS) environmental-analysis system developed by the U.S. Environment Protection Agency and AQUA TERRA Consultants (U.S. Environmental Protection Agency, 2013).

In addition to the several hydrograph-analysis methods, the GW Toolbox includes functions that retrieve hydrologic time-series data (streamflow, groundwater levels, and precipitation) from the USGS National Water Information System (NWIS) Web interface (U.S. Geological Survey, 2013), that download preprocessed GIS data layers and meteorological data from the National Oceanic and Atmospheric Administration (NOAA) National Climatic Data Center (NCDC), and that analyze data with several preprocessing and postprocessing utilities. The data retrieval and analysis tools provided by the GW Toolbox also can be used to estimate several of the components of the water budget for a hydrologic basin, including precipitation; streamflow; base flow; runoff; groundwater recharge; and total, groundwater, and near-surface evapotranspiration.

The primary purpose of this report is to provide a set of instructions that will allow users of the GW Toolbox to quickly develop skills to use its mapping, data-retrieval, datainspection, and hydrograph-analysis tools to estimate base flow, surface runoff, and groundwater recharge for a hydrologic basin. A secondary objective is to illustrate how the GW Toolbox can be used to develop a water budget for basins that have little to no groundwater withdrawals or streamflow regulation. The report supplements information that is available in the 'GW Toolbox Documentation' manual provided with the GW Toolbox. The online documentation is an integral part of the GW Toolbox software. In several cases, there are alternative approaches for completing work tasks; these alternatives can be found in the documentation.

\section{Base-Flow, Runoff, and Recharge Estimation Methods and Applicability}

Version 1.0 of the GW Toolbox includes six hydrograph-separation methods to calculate base flow-the BaseFlow Index (BFI; Standard and Modified), HYSEP (Fixed Interval, Sliding Interval, and Local Minimum), and PART methods - and a single recession-curve displacement method to calculate groundwater recharge- - the RORA method. Each of the four computer programs in which the methods were originally implemented were reprogrammed from their original Fortran language into the Visual Basic.Net language within Microsoft Visual Studio .NET.

Each method uses a time series of daily mean streamflow (discharge) measured at a streamgage as the basis for estimating either base flow or recharge. Surface-water runoff is calculated as the difference between total streamflow and the calculated base flow. Each method requires specification of the drainage area of the basin ( $A$, in square miles), which is used to convert volumetric flow rates of streamflow, base flow, runoff, and recharge (in cubic feet per second) to flow rates per unit area over the contributing drainage area (in inches). Drainage area also is needed for the HYSEP, PART, and RORA methods to calculate the duration of surface runoff for the basin $\left(N_{s r}\right.$, in days; Sloto and Crouse, 1996; Rutledge, 1998):

$$
N_{s r}=A^{0.2} .
$$

For convenience, the GW Toolbox will automatically retrieve the drainage area of the streamgage if it is available as an attribute of the streamgage in NWIS.

The seven hydrograph-analysis methods, as well as any changes that were made to the programs for implementation in the GW Toolbox, are described briefly here; each method is described in detail in the references cited. A full understanding of these references is integral to the proper application of the methods. Those readers unfamiliar with the methods in the GW Toolbox should review the relevant references before applying the methods.

BFI.-The BFI program (Wahl and Wahl, 1995) is based on a set of procedures developed by the Institute of Hydrology $(1980 \mathrm{a}, \mathrm{b})$ in which the streamflow record is partitioned into intervals of length $N$-days. The minimum streamflow during each $N$-day interval then is identified and compared to adjacent minimums to determine "turning points." If 90 percent of a given minimum (the "turning point test factor") is less than both adjacent minimums, then that minimum is a turning point. The base-flow hydrograph is completed by connecting the turning points. The original BFI program set $N$ to 5 days; the current version allows the user to vary the values of $N$ and the turning point test factor $(f)$ to "... permit tuning the algorithm for different watersheds or to match other base-flow separation methods" (Wahl and Wahl, 1995). In the BFI-modified approach, parameter $f$ is replaced by a daily recession index $K^{\prime}$, and the turning-point test considers the exact number of days between turning-point candidates. Results obtained by the modified approach will usually be very similar to those obtained by the standard approach if

$$
K^{\prime}=f^{\left(\frac{1}{N}\right)} .
$$


For values of $N=5$ days and $f=0.9$, the equivalent value of $K^{\prime}$ is 0.979 (Tony L. Wahl, Bureau of Reclamation, written commun., 2012). One modification was made to the BFI program for implementation in the GW Toolbox. In the original program, turning points were identified for each individual year, with partitioning restarted on day 1 of each year, and artificial (or virtual) turning points were created at the yearend boundaries. In the GW Toolbox implementation, turning points are identified continuously throughout the entire period of record, which avoids the creation of artificial turning points at the end of each year. This modification also changes how the daily values are partitioned after a year is completed in which the number of days in the year is not an even multiple of $N$. In test problems, the modification generally produced very small differences in calculations between the original program and the implementation of the program in the GW Toolbox when short time periods are considered; these differences increased, however, but were still generally small, as the number of years analyzed increased because of increasingly divergent values of the turning points selected by the two approaches.

HYSEP.-The HYSEP software (Sloto and Crouse, 1996) uses three methods originally developed by Pettyjohn and Henning (1979) to separate base-flow and runoff components of a streamflow hydrograph: the fixed interval, sliding interval, and local minimum methods. The three methods use different algorithms to draw connecting lines (the base-flow hydrograph) between low points of the streamflow hydrograph. No changes were made to the HYSEP algorithms for the GW Toolbox.

PART.-The PART program (Rutledge, 1998) equates base flow to streamflow on days that are designated as being unaffected by surface runoff or interflow (stormflow), and linearly interpolates between these days to determine base flow for the remainder of the hydrograph. Days that are unaffected by surface runoff are identified by the program as those preceded by $N_{s r}$ days of continuous recession (see Rutledge, 1998, p. 34-36; Rutledge, 2007). One small change was made to PART for implementation in the GW Toolbox. In the original program, each daily value of base flow was calculated by running the program three times for three different values of $N_{s r}$; a curvilinear interpolation of the three calculated values was then done to determine the final value of base flow for each day (see Rutledge, 1998, p. 34-35). Although the GW Toolbox still runs PART three times for each streamflow record (and reports the values for each run in output file partday.txt), only the results of the first two values of $N_{s r}$ are used to calculate the final, reported value of base flow on each day (in output file daily.csv). This was done for consistency with the method used by the program to calculate monthly and annual values of base flow.

RORA and RECESS.-The RORA program uses the recession-curve displacement method developed by Rorabaugh (1964) to estimate groundwater recharge for each peak in a streamflow hydrograph (Rutledge and Daniel, 1994; Rutledge, 1998). The method is based on a mathematical expression for the total volume of water that will drain from an aquifer following each recharge event. RORA requires that the user specify a recession index, $K$, for the basin. $K$ can be determined in practice as the time required for groundwater discharge to decline through one log cycle on a semilogarithmic plot of the logarithm of streamflow as a function of time. Program RECESS, which also was developed by Rutledge (1998) and is included in the GW Toolbox, can be used to estimate $K$ from a streamflow hydrograph during prolonged periods of negligible recharge. No changes were made to the RORA or RECESS algorithms for the GW Toolbox.

Each of the seven hydrograph-analysis methods is based on a number of simplifying assumptions that limit their applicability. These assumptions are described by many investigators, including Sloto and Crouse (1996), Rutledge (1998, 2000, 2007), and Healy (2010), and are discussed in the remainder of this section. Moreover, although the programs calculate daily and (or) monthly values of base flow, runoff, and recharge, the estimates are most reliable when averaged over longer time periods, such as years.

The methods should be applied to the analysis of streamflow hydrographs that reflect contributions from two sources: surface runoff in response to a precipitation event and groundwater discharge from a single aquifer. The methods are intended for application to basins dominated by diffuse areal groundwater recharge that is uniformly distributed over a basin, rather than basins in which focused groundwater recharge, such as occurs from losing stream reaches, is the dominant recharge pathway. All groundwater recharge within the basin is assumed to discharge to the receiving stream network except that amount that is evapotranspired directly from the groundwater system (sometimes referred to as riparian evapotranspiration). As noted by Rutledge (2007) and Healy (2010), the hydrograph-separation methods also are based on the assumption that groundwater discharge to streams is a continuous process, whereas the recession-curve displacement method is based on the assumption of episodic recharge in response to storms. Several studies cited by Rutledge (2007) and Healy (2010, p. 89), have found that recharge estimates determined from the recession-curve displacement method are generally greater than those estimated by the hydrographseparation methods, as implied by the assumption that some groundwater recharge discharges by riparian evapotranspiration instead of by discharge to the stream network.

The assumption that all groundwater recharge either discharges to the stream or by groundwater evapotranspiration implies that the surface-water and groundwater drainage areas to the streamgage are coincident. Moreover, it is assumed that there is no loss of groundwater to underlying regional groundwater-flow systems or to groundwater withdrawals.

A number of hydrologic processes and human activities that affect the flow and storage of water within a basin can obscure the contributions from surface runoff and groundwater discharge to a streamflow hydrograph. These include snowmelt runoff and drainage from large lakes and wetland areas. Streamflow regulation, such as occurs at reservoirs, by streamflow diversions, or by wastewater return flows, also changes 
the natural flow of a stream. The algorithms that are the basis for the methods available in the GW Toolbox cannot differentiate among the various causes of hydrograph fluctuations and may incorrectly identify snowmelt, reservoir releases, and so forth as groundwater discharge. Therefore, users should understand the hydrologic conditions in a basin to confirm the quantitative results of the hydrograph-analysis methods.

Rutledge $(1998,2000)$ provides guidance on the size and slope of basins to which the methods should be applied. He suggests that the methods should not be applied to basins having drainage areas smaller than 1 square mile $\left(\mathrm{mi}^{2}\right.$; about 3 square kilometers $\left[\mathrm{km}^{2}\right]$ ), so that the duration of surface runoff exceeds the minimum time increment of streamflow data (1 day). A maximum drainage area of about $500 \mathrm{mi}^{2}$ (about 1,300 $\mathrm{km}^{2}$ ) also is recommended, but the upper limit on basin size will depend on the degree of uniformity of rainfall over the basin, the occurrence of multiple hydrogeologic areas within the basin, and the relative importance of bank-storage effects. Rutledge (2000) further notes that, in basins with extremely low relief, the time period of surface runoff may not be accurately determined by use of equation 1 ; the effect of low slope on the analysis is likely to be exacerbated as the drainage basin increases in size.
There has been some discussion in the literature concerning the various limitations of the RORA method for estimating groundwater recharge. Healy (2010, p. 89-90), for example, notes that "Few, if any, aquifers conform to all of the assumptions inherent in the derivation of the recession-curve displacement method." Halford and Mayer (2000) and Halford (2008) question the use of equation 1 to determine the duration of surface runoff from a basin, the use of streamflow records to estimate an appropriate recession index $(K)$, and the effects of hydrologic phenomena such as bank storage and snowmelt on the identification of recharge peaks in a streamflow record. Nevertheless, there have been many applications of the RORA method since the initial release of the program in 1994 (Rutledge and Daniel, 1994) and these applications have resulted in recharge values that are consistent with other basinscale recharge-estimation methods. The reader is referred to Rutledge (2007) and Healy (2010, p. 89-90) for reviews and summaries of these several studies, and to Risser and others (2005) and Delin and others (2007) for detailed studies in which results of the RORA method were compared to other recharge-estimation methods in humid regions.

Figure 1 summarizes several of the assumptions and limitations of the hydrograph-analysis methods provided with the

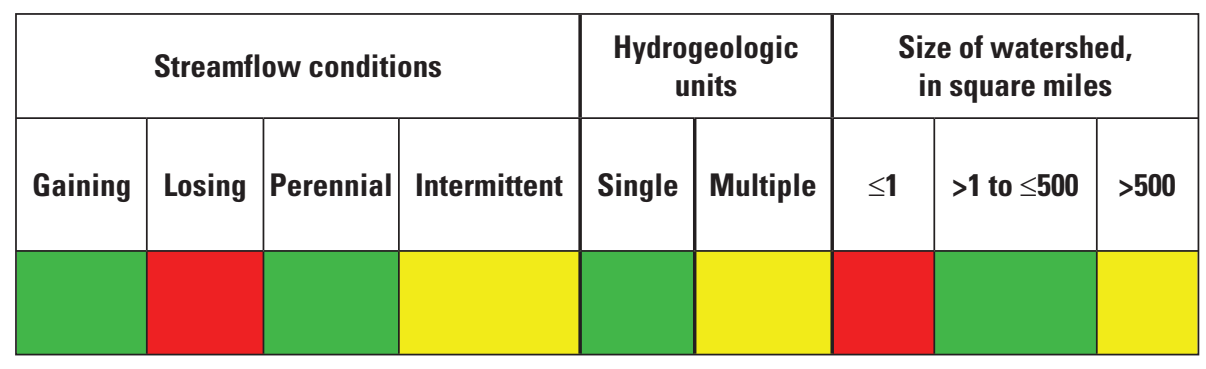

\section{EXPLANATION}

Appropriate

Caution

Not appropriate

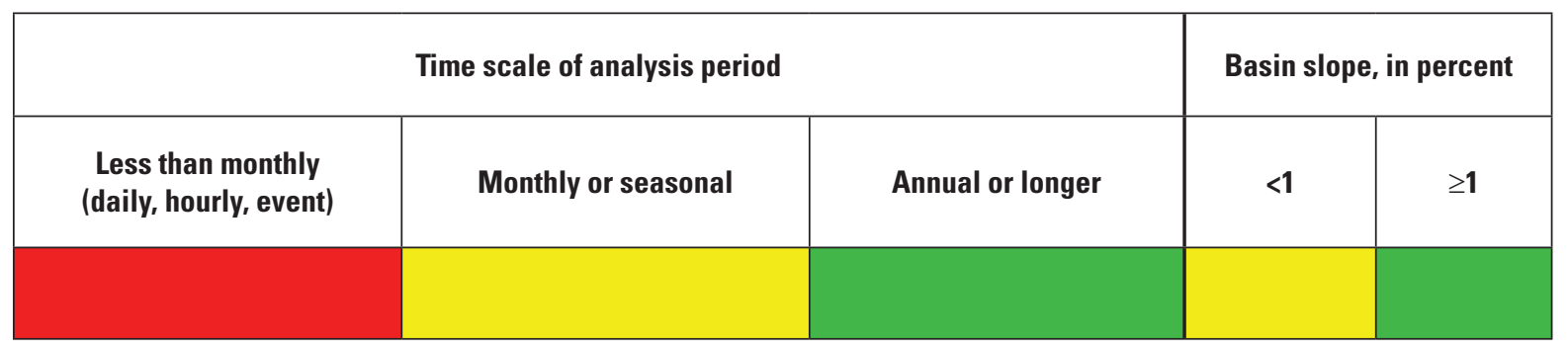

\begin{tabular}{|c|c|c|c|c|}
\hline \multicolumn{2}{|c|}{$\begin{array}{c}\text { Groundwater or surface-water development } \\
\text { (groundwater pumping, surface-water discharges or diversions, and so forth) }\end{array}$} & \multicolumn{2}{c|}{ Streamflow record } \\
\hline None & $\begin{array}{c}\text { Relatively minor } \\
\text { (small component of typical } \\
\text { low-flow conditions) }\end{array}$ & $\begin{array}{c}\text { Substantial } \\
\text { (large component of typical } \\
\text { low-flow conditions) }\end{array}$ & $\begin{array}{c}\text { Complete and } \\
<1 \text { year in length }\end{array}$ & $\begin{array}{c}\text { Complete and } \\
\geq 1 \text { in length }\end{array}$ \\
\hline & & & \\
\hline
\end{tabular}

Figure 1. Guidance on appropriateness of hydrograph-analysis methods provided with the Groundwater Toolbox $1<$, less than; >, greater than; $\leq$, less than or equal to; $\geq$, greater than or equal to). 
GW Toolbox as a guide for their use. In determining whether or not the methods are appropriate for a particular basin, the overall weight of the guidance provided in figure 1 should be considered. For example, a user could be fairly confident that the methods could be applied meaningfully to a gaining, perennial stream in a basin of about $100 \mathrm{mi}^{2}$ in drainage area, but should be very cautious applying the methods to an intermittent stream with a drainage area of $1,000 \mathrm{mi}^{2}$ and very low slope. Because of the several assumptions and guidelines described above, the authors of this report agree with the conclusion reached by Healy (2010, p. 96) concerning application of the hydrograph-analysis methods "...that a complete evaluation of these assumptions may require substantially more effort than actual application of the methods." When possible, the methods should be combined with other types of data to confirm the hydraulic interaction of groundwater/ surface-water systems, such as simultaneous measurements of groundwater levels and stream stages, seepage-meter measurements, seepage runs, and chemical and heat tracers (Stonestrom and Constantz, 2003; Rosenberry and LaBaugh, 2008; Eddy-Miller and others, 2012).

\section{Example Basin}

The methods provided with this initial version of the GW Toolbox are demonstrated with streamflow data collected at the streamgage on the Pawcatuck River at Wood River Junction, Rhode Island (USGS streamgage 01117500). The drainage area to the streamgage is $100 \mathrm{mi}^{2}$. Approximately 42 percent of the basin is underlain by stratified-drift glacial deposits, which constitute the primary aquifer. The remainder of the basin is underlain by bedrock or till-covered bedrock, which constitutes a secondary aquifer, in the upland areas (Cervione and others, 1993). The Pawcatuck River streamgage was selected because conditions at the site closely - but not exactly - meet the major assumptions of the hydrograph-separation and recharge-estimation methods. Specifically, recharge to the aquifer is areally diffuse and there is little water use or streamflow regulation in the basin (Bent and others, 2011). However, groundwater and surface-water drainage basins to the streamgage are not completely coincident because some groundwater outflow is known to occur across the northeastern boundary of the drainage basin and groundwater inflow is suspected to occur across the western boundary of the basin (Bent and others, 2011). Nevertheless, these rates of groundwater flow are small compared to the total flow at the streamgage and are unlikely to have a substantial effect on the results of the analysis. The period of analysis was the 30-year period extending from January 1, 1971, through December 31,2000 . This period was chosen for consistency with other studies in the basin and because of the availability of meteorological data from a weather station within the basin for this time period.

\section{Getting Started}

The first steps in the use of the GW Toolbox for any analyses are to build a GW Toolbox project for the geographic area of interest, retrieve spatial and time-series datasets to populate the project, and review the time-series data. This section of the report provides instructions that can be used to complete these tasks. It is assumed that the GW Toolbox has already been installed on the user's computer; information on how to download and install the program can be found at the Web site provided in the Preface to this report.

A number of text-formatting conventions are used throughout the report. Components of the GW Toolbox interface, such as dialog boxes, panels, or buttons, are referred to in quotes, such as the "Preview Map" panel. Specific menu options and tools are referred to by bold text, such as the "Open Project" option in the "File" menu, which is available on the main toolbar.

\section{Building, Saving, and Reopening a Project}

A GW Toolbox project is a collection of spatial and time-series data and analysis results for a specific geographic area. The project area can consist of a State, county, or HUC-8 hydrologic cataloging unit. A cataloging unit is one of the divisions of the hydrologic unit code (HUC) classification system of river basins in the United States (Seaber and others, 1987). Each cataloging unit is given an 8-digit code; for example, the Pawcatuck River streamgage is within the Pawcatuck-Wood cataloging unit (01090005). (Cataloging units also are referred to as basins in this report.)

Double-clicking on the "USGS GW Toolbox" icon results in the two dialog boxes shown in figure 2: the "USGS GW Toolbox 1.0" and "Welcome to USGS GW Toolbox 1.0" dialog boxes. If the GW Toolbox has not previously been used, the user should select the "Build New Project" option. Selecting this option produces a map of the United States showing the boundaries of States and cataloging units (fig. 3). The user can then zoom into an area of interest with the "Pan" and "Zoom" tools.

Labels can be added to identify the cataloging units in a zoomed-in view. This is done by right-clicking on the Cataloging Units layer, which results in several menu options (fig. 4A); in this example, the user selects the "Label Setup" option, which opens the "Label style" dialog box (fig. 4B). The user double-clicks on the "CU" field and then selects the "Apply" check box. A label-generation dialog box then appears (not shown on fig. 4) that allows the user to select the position and orientation of the labels. Once these are selected, the cataloging-unit labels are added to the map (fig. 4C).

The "Select" tool can then be used to select the cataloging unit of interest (01090005, fig. 5A). The user selects the "Build" check box from the "Build New USGS GW Toolbox 1.0 Project" dialog box (fig. 3). At this point, the GW Toolbox will prompt the user with a "Save new project as..." dialog 


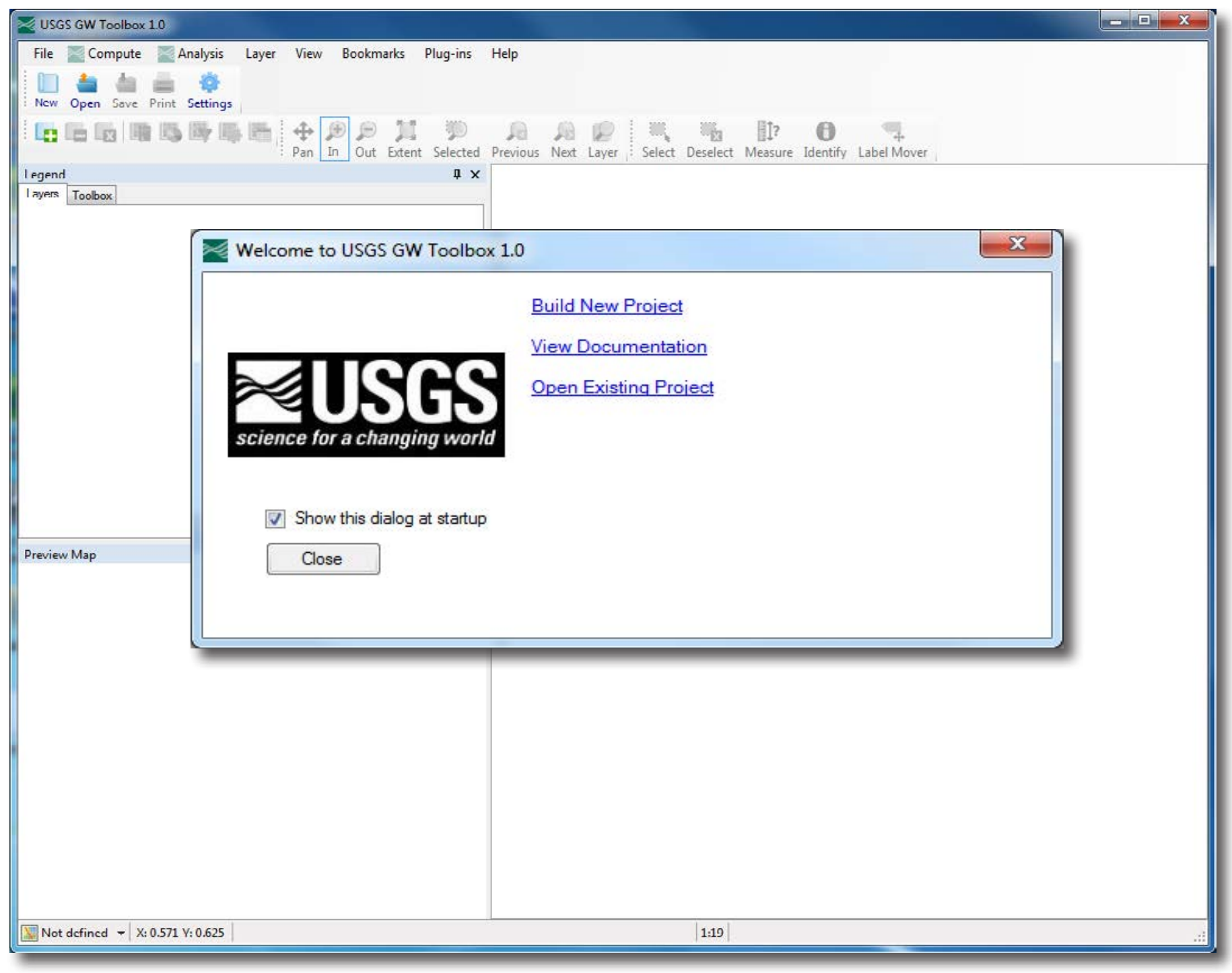

Figure 2. The "Welcome to the USGS GW Toolbox 1.0" and "USGS GW Toolbox 1.0" dialog boxes that appear on first use of the Groundwater Toolbox.

box to select a directory name and location in which to save the project. The default location in which to save the project is the C: \USGS-GWToolbox \data directory, and a subdirectory is created for the project with the HUC- 8 code as the default directory name (which in this example is 01090005). Project information is stored in a MapWindow project file in the project directory (.mwprj file) with the HUC-8 code in the default file name (01090005.mwprj). If multiple projects have been created for the HUC-8 area, a sequence number will be appended to the subdirectory and project names (for example, 01090005-2). A "Projection Properties" dialog box will appear and the user can select the desired projection for the project data layers [the default "Albers Equal-Area (Conterminous U.S.)" option was selected for this example]. The project then will be populated with a set of standard data layers. To view all of the layers that are active, it is helpful to close the "Preview Map" panel by clicking on the "X" on the top right of the "Preview Map" panel or by toggling off the check-mark in the "Preview Map" section from the "Panels" option in the "View" menu. The resulting map and data layers are shown in figure $5 \mathrm{~B}$.

It should be noted that the "Welcome to USGS GW Toolbox 1.0" dialog box can be reopened at any time using the "Welcome Screen" option from the "Help" menu. Also, as an alternative to the approach described in the previous paragraphs, a new project can be built by selecting the "New" option from the "File" menu. An existing project can be reopened from the "Welcome to USGS GW Toolbox 1.0" dialog box or with the "Open Project" or "Open GW Toolbox Project" options from the "File" menu. 


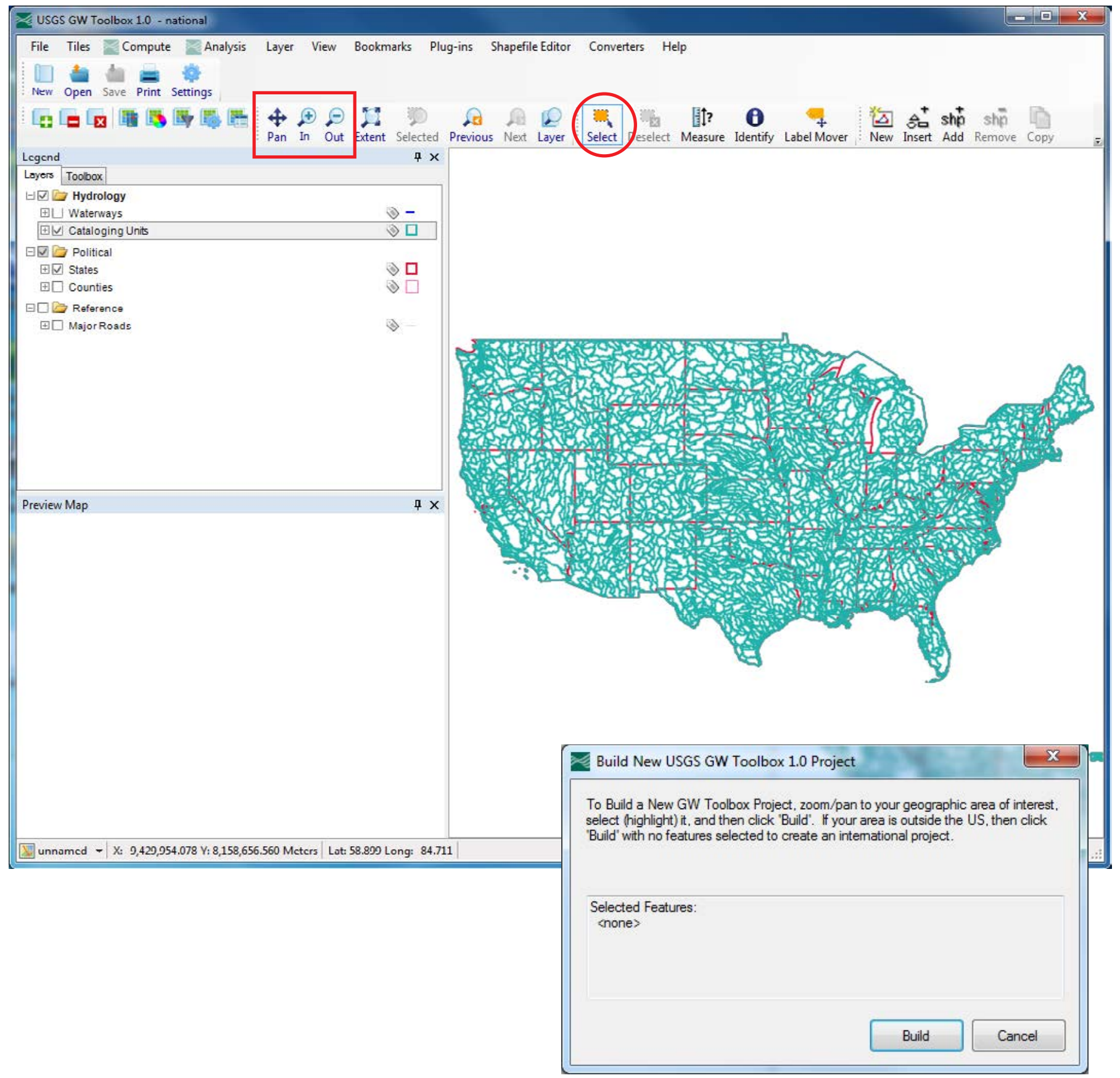

Figure 3. The initial map with data layers active that show states and hydrologic cataloging units. "Pan," "Zoom In," "Zoom Out," and "Select" tools are identified.

\section{Time-Series Data Discovery and Retrieval}

When a GW Toolbox project is created, a large cache of map layers is downloaded and stored in the project directory. A subset of these layers, which is shown in the "Legend" panel (fig. 5B), is made available as part of the initial build of the project. Data-collection sites for several types of observed data are shown by default on the project map. These are sites at which a minimum of 10 data values of daily streamflow (discharge), daily groundwater levels, and periodic groundwater levels are available through the NWIS database. The sites with periodic groundwater-level data are not actively displayed on the map because they tend to be numerous and are not of primary interest for the tools described in this report. Their locations can be seen by toggling the check-box next to the layer identifier to the "on" position.

The first step in data retrieval is to select specific data sites from the project map for which data will be downloaded 
$\boldsymbol{A}$

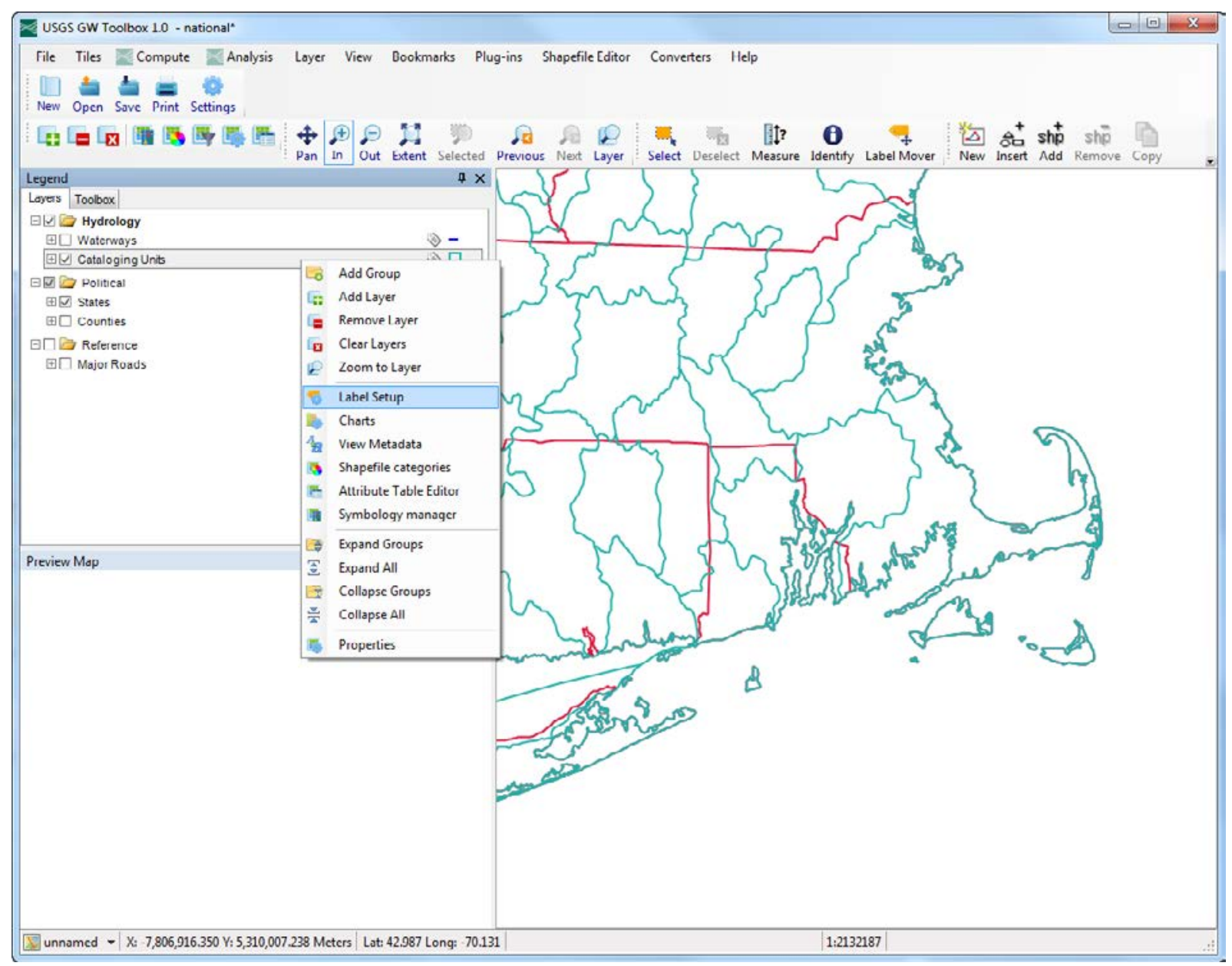

$\boldsymbol{B}$

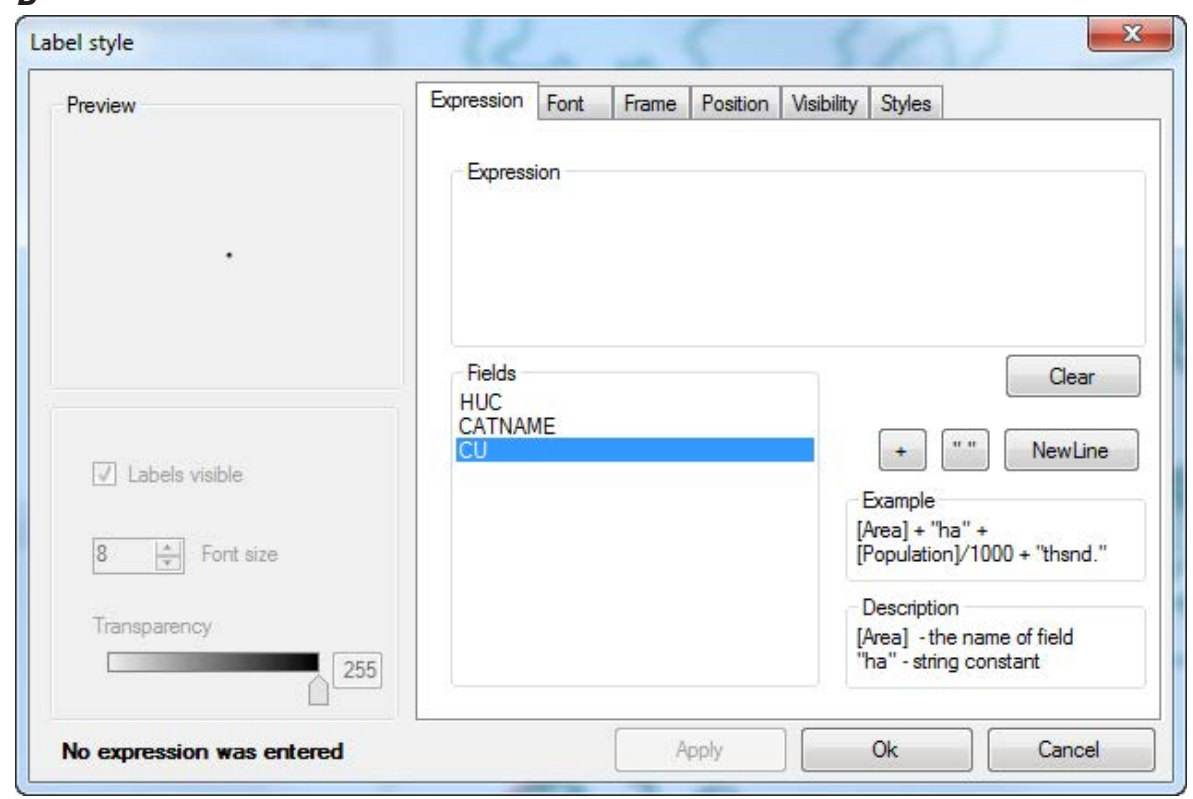

Figure 4. The method for adding labels to a map layer. In this example, cataloging-unit numbers are added to the Cataloging Units layer. A, Options available by right-clicking on the selected layer, "Cataloging Units." B, "Label-style" dialog box that appears after selecting the "Label Setup" option. 


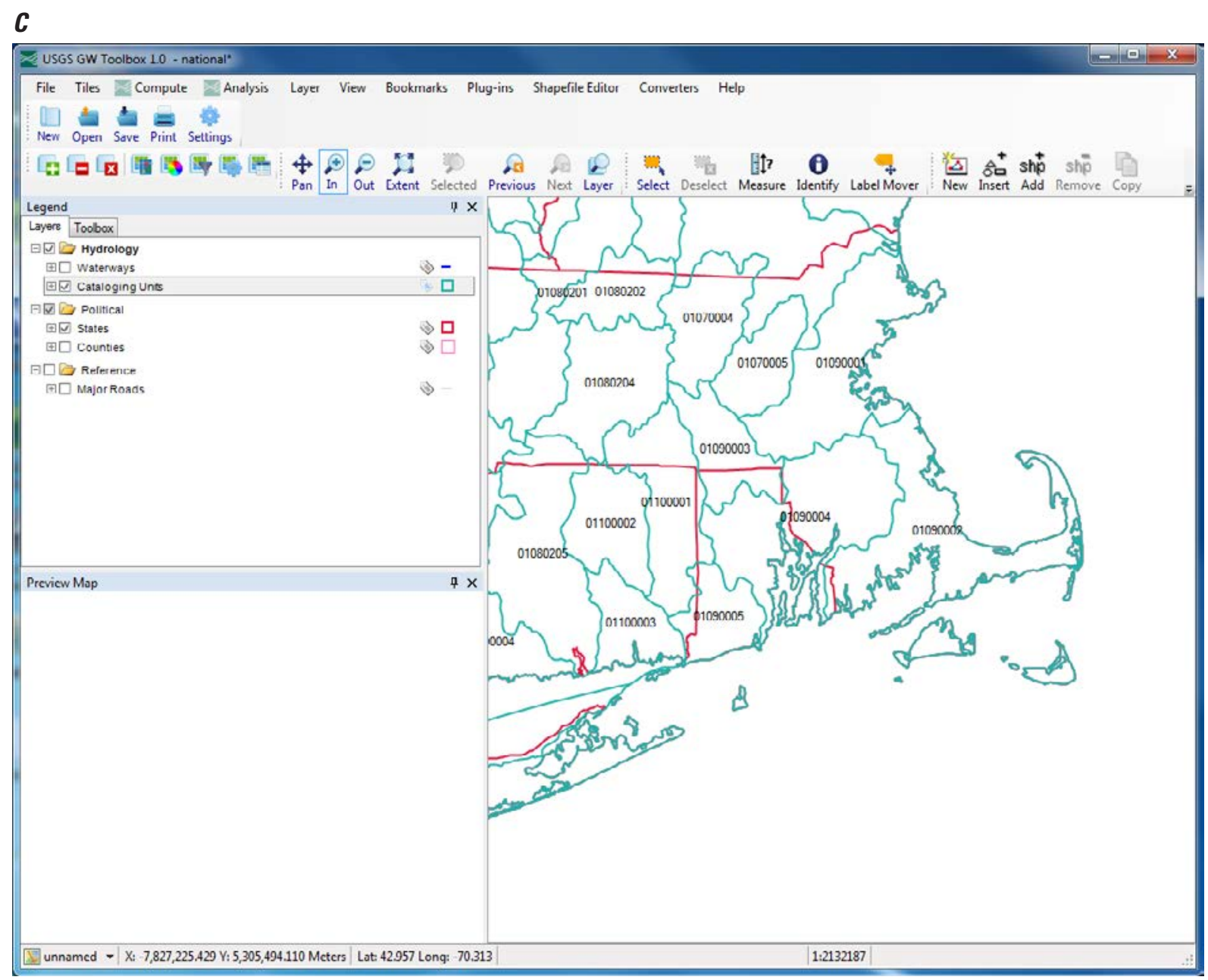

Figure 4. The method for adding labels to a map layer. In this example, cataloging-unit numbers are added to the Cataloging Units layer. $\boldsymbol{C}$, The resulting map, with cataloging-unit labels added.-Continued

from NWIS. For this example, streamflow data will be retrieved because they are needed for the base-flow and recharge analyses. The discharge-locations data layer shown on the map indicates that there are several streamgages within and near the Pawcatuck-Wood Basin (fig. 5B). At this point, it is convenient to either add the streamgage numbers using the "Label Setup" option, as described previously (fig. 4), or to import a data layer of the drainage-basin boundary for the streamgage of interest, if one is available. For this example, a shapefile of the drainage basin for the Pawcatuck River at Wood River Junction streamgage (01117500) was imported by use of the "Add Layer" option from the "Layer" menu. Streamgage identifiers also were added to the map (fig. 6). To select a streamgage, the user clicks on the data layer of interest ("NWIS Daily Discharge Stations"; fig. 6, step 1) and then clicks on the "Select" tool (fig. 6, step 2). The user can then select the streamgage of interest by clicking on it (fig. 6, step 3 ). Alternatively, one or more streamgages of interest can be selected by drawing a box around them with the "Select" tool or by using the "Ctrl" key on the keyboard and "Select" tool to select multiple stations for download. The selected stations will then appear grayish yellow on the map.

After a site is selected, the "Download Data" option from the "File" menu can be used to retrieve data from NWIS for the station (fig. 7A). As shown on figure 7A, there are several types of data that can be downloaded, but for this example the "Daily Discharge" button within the "Data Values from US Geological Survey National Water Information System" panel already has been selected because of the steps completed in the previous paragraph. The user then clicks the "Download" button and data for the selected site are retrieved (there is a pause as the data are retrieved). The user is then informed that data for the selected site have been retrieved and saved in a file that uses the USGS NWIS RDB (relational database) timeseries format (fig. 7B). The daily discharge data are reported in units of cubic feet per second (USGS NWIS parameter code 00060). The data are now part of the project and available for use in the GW Toolbox.

Similar steps were taken to retrieve daily groundwater-level data for observation well RI-EXW 554 (USGS 
A

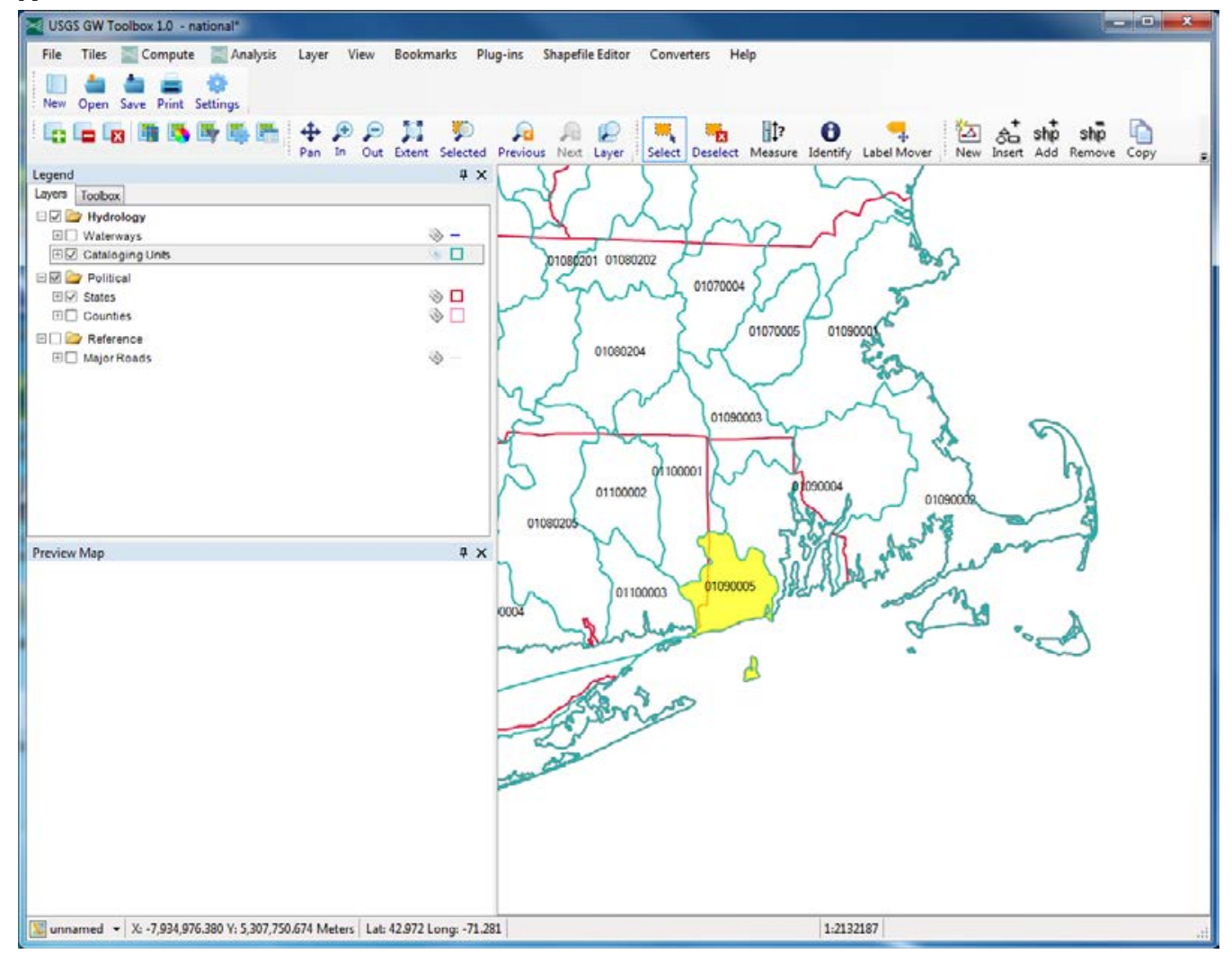

$\boldsymbol{B}$

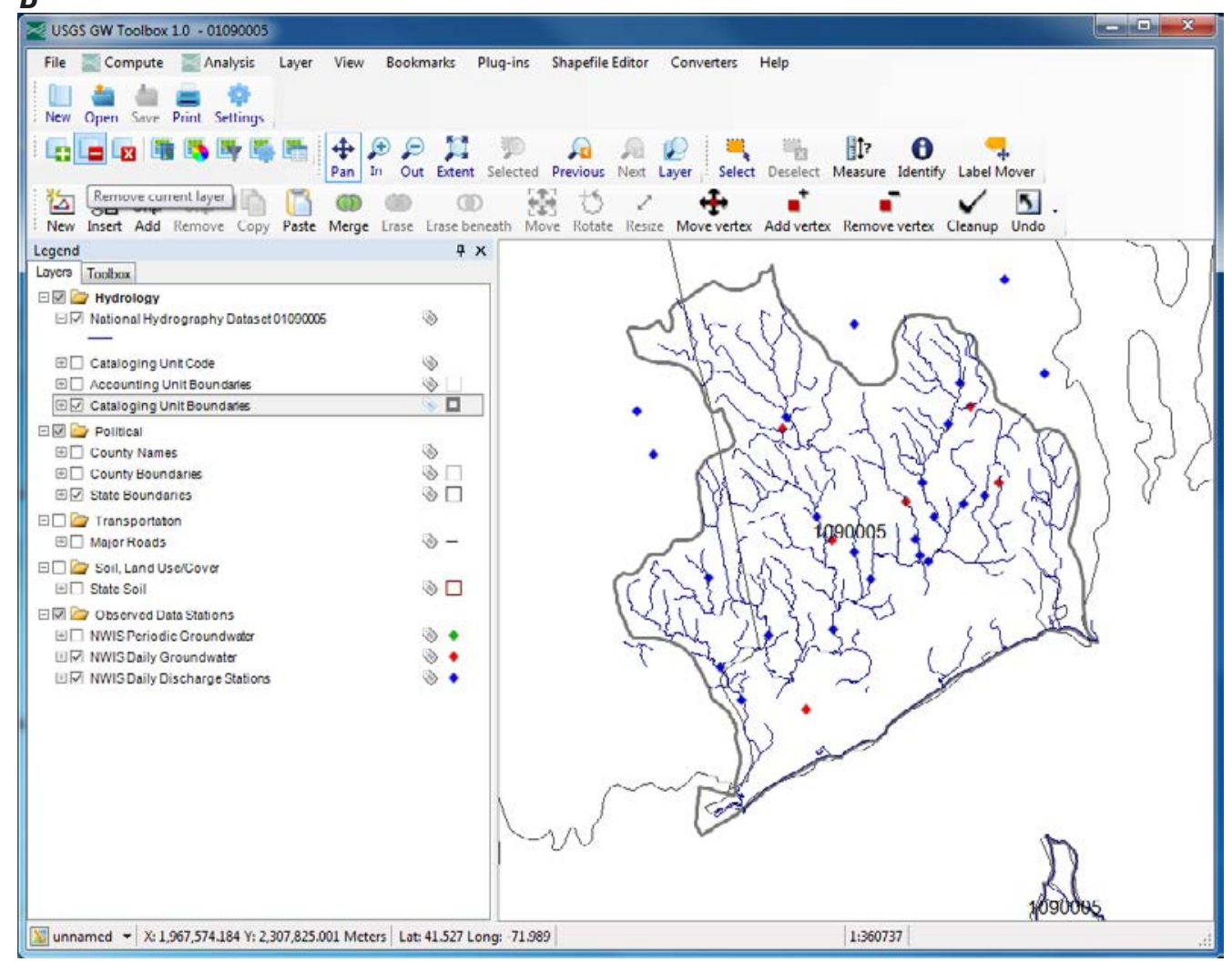

Figure 5. Selected steps to build a Groundwater Toolbox project. A, The "Select" tool is used to select the cataloging unit (basin) of interest, which is then shaded yellow. B, The resulting map, which includes daily streamflow (discharge) and groundwater-level datacollection locations for the basin of interest and surrounding area. 
observation well 413252071323601), which is within the Pawcatuck River Basin. Groundwater-level data are stored in NWIS in a number of formats; for example, depth to water level in feet below land surface (parameter code 72019) or elevation of water (parameter code 72020). The GW Toolbox converts all data formats to depth to water level, in feet below land surface.

As part of the data-discovery process, it can be advantageous to add other data layers to complement the default data layers shown on the project map. This can be done by toggling inactive data layers shown on the "Legend" (such as "Major Roads") to active (by clicking on the check boxes next to each data layer) or by retrieving data layers that have been preprocessed for the GW Toolbox and are available for download. These data layers are listed on the "Download Data" dialog box (fig. 7A). After the user selects a particular data layer and then clicks on the "Download" button, there may be a pause while the requested data files are downloaded and projected, merged, and clipped as needed to the download region (which, in this case, is hydrologic unit 01090005). When the download is complete, the user will be returned to the GW Toolbox interface, and the added layers will appear on the explanation and map.

The user also can adjust the minimum number of measurement values required at an observation site for the site to be shown on the project map. This is done by adjusting the value specified in "Min Count" on the "Download Data" dia$\log$ box. The default value for "Min Count" is 10 measurement values, but this value can be modified. After the value of "Min Count" is adjusted for a selected data type ("Daily Groundwater," "Periodic Groundwater," and so forth), the user clicks on the "Download" button, which causes the map to be updated with sites that meet the minimum specified count.

\section{Summarizing, Listing, and Graphing Time-Series Data}

It is important to carefully screen the streamflow data prior to a hydrograph analysis to identify suspect data and to confirm that the data are consistent with the underlying assumptions of the analysis methods (Sloto and Crouse, 1996). The GW Toolbox provides three tools that are useful in this regard: the "Data Tree," "List," and "Graph" tools under the "Analysis" menu option. The "Data Tree" tool provides a listing of many of the attributes and summary statistics for the dataset, whereas the "List" tool provides a listing of the complete dataset. Each of the three tools is explained in detail in online documentation under the "Help" menu option.

Selection of any of the three tools brings up either the "Select Data" or "Select Data to Graph" dialog boxes (fig. $8 \mathrm{~A}$ ), which allow the user to select one or more time-series

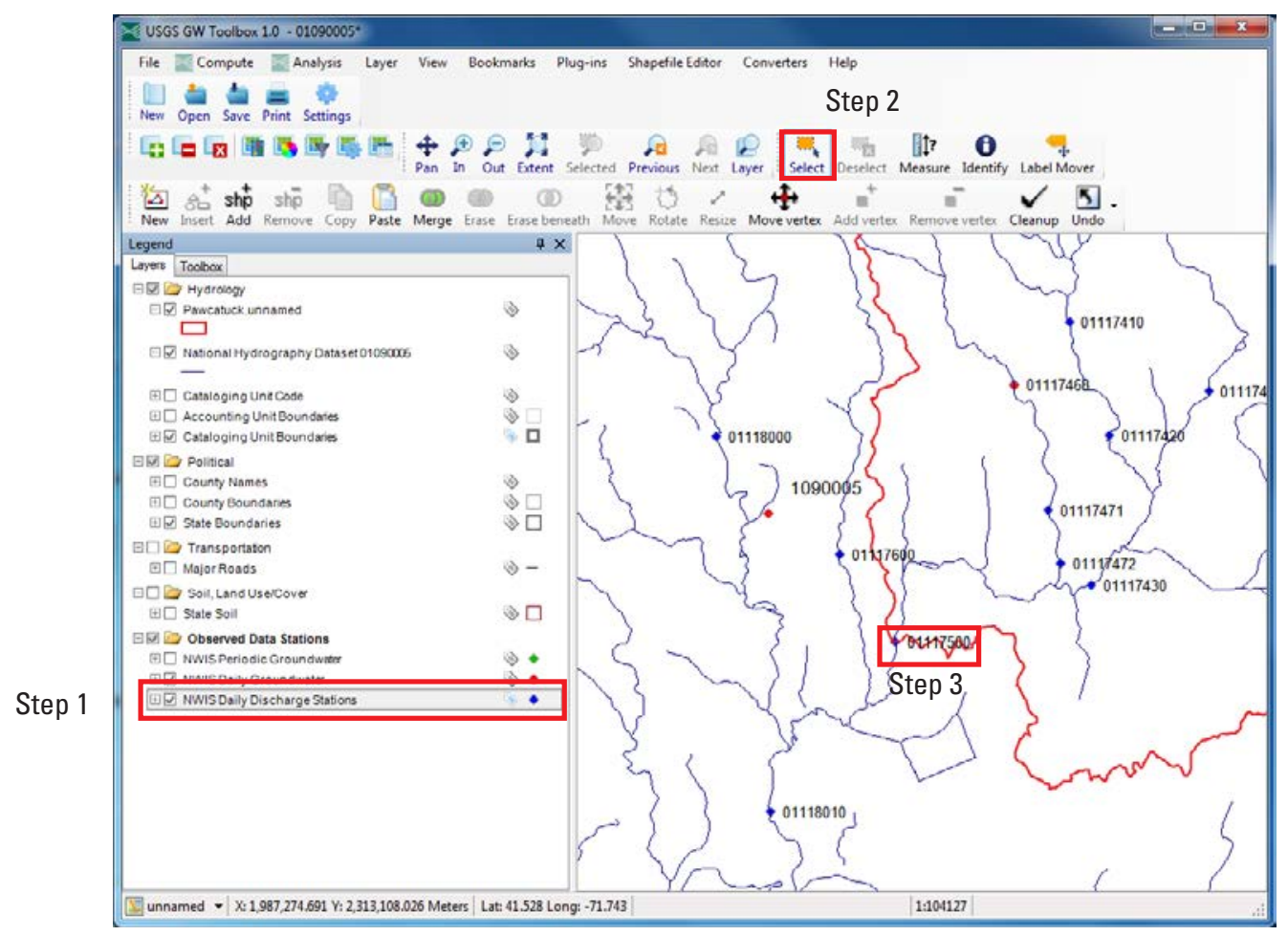

Figure 6. Steps used to select one or more data sites for which data can be retrieved from the U.S. Geological Survey National Water Information System for use in the Groundwater Toolbox. In this example, the streamgage on the Pawcatuck River at Wood River Junction, Rhode Island, is selected (site 01117500). Steps are discussed in the text. Part of the drainage basin for the streamgage is shown in red. 
datasets available for the project. For this example, the "Graph" option will be illustrated. The top section of the "Select Data to Graph" dialog box is titled "Select Attribute Values to Filter Available Data" and contains dropdown lists with time-series attributes. The number and content of these lists can be managed through the "Attributes" menu. The default attributes that are shown with the GW Toolbox are "Scenario," "Location," and "Constituent," but these default selections can be changed by the user. Attributes are shown in figure 8 for two observed datasets that were retrieved in previous steps: the streamflow data for streamgage 01117500 and the groundwater-level data for observation well 413252071323601. When the user selects an attribute from any of the lists, the "Matching Data" section is populated with the datasets that meet the attribute(s) selected. In the example shown on figure 8A, "Streamflow" has been selected from the "Constituent" attribute list (step 1), which brings up the only matching dataset at streamgage 01117500 . The user then selects this streamgage (step 2) and the selected time series shows up in the "Selected Data" section of the dialog box (step 3). Note that the complete date range of the streamflow dataset is shown in the "Dates to Include" section of the dialog box; the "Start" and "End" dates of the graph can be modified in the white fields. The user then clicks on "Ok" to bring up the graphing options (fig. 8B). For this example, both the timeseries and flow-duration plots are selected.

The time-series graph (and list of the data, which is not shown) indicate that data are complete throughout the period of record (December 7, 1940, through November 5, 2014; fig. 9A); however, data for the period October 1 through November 5, 2014, are provisional data that have not yet been approved for publication by the USGS. These provisional data

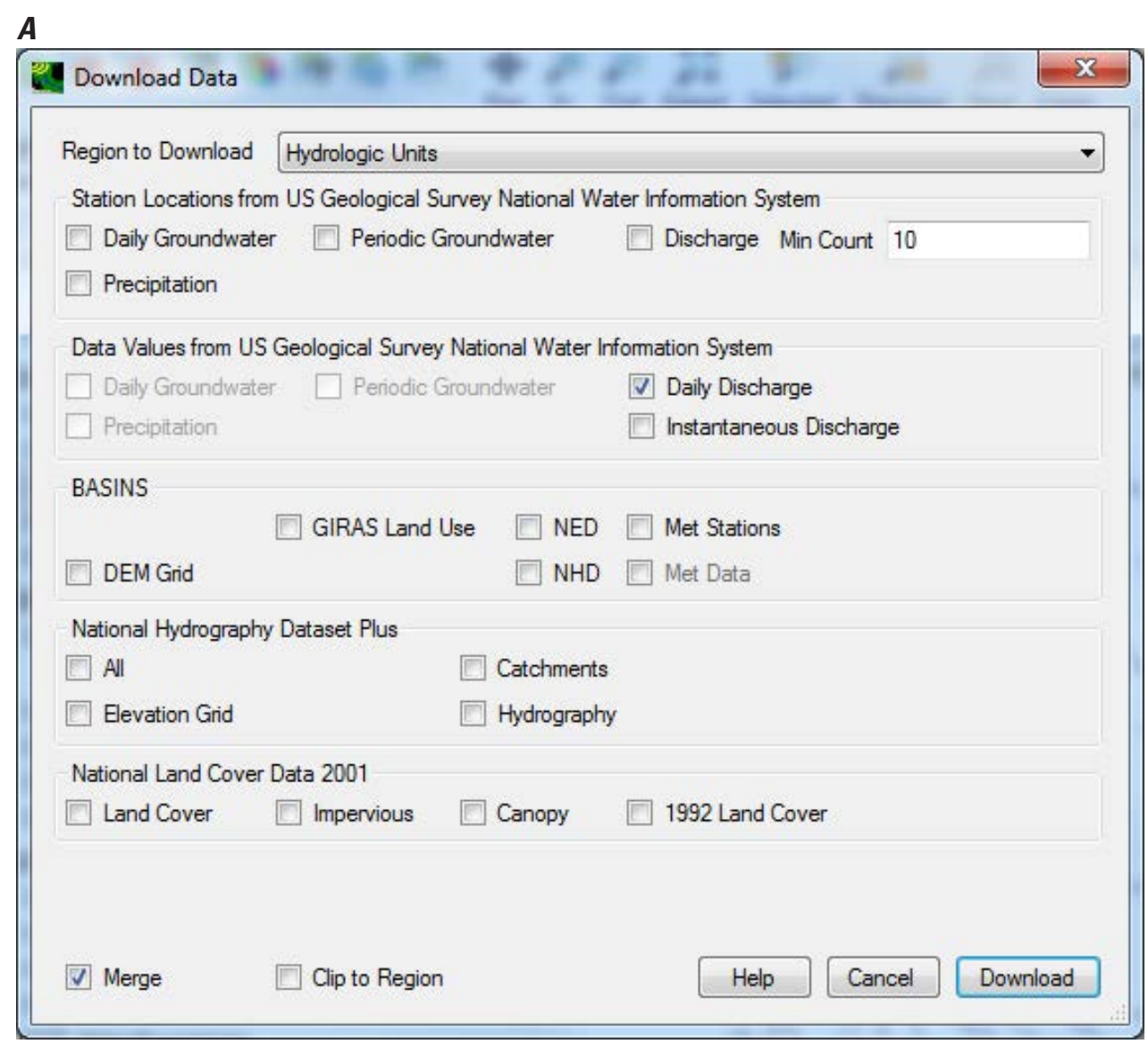

\section{B}

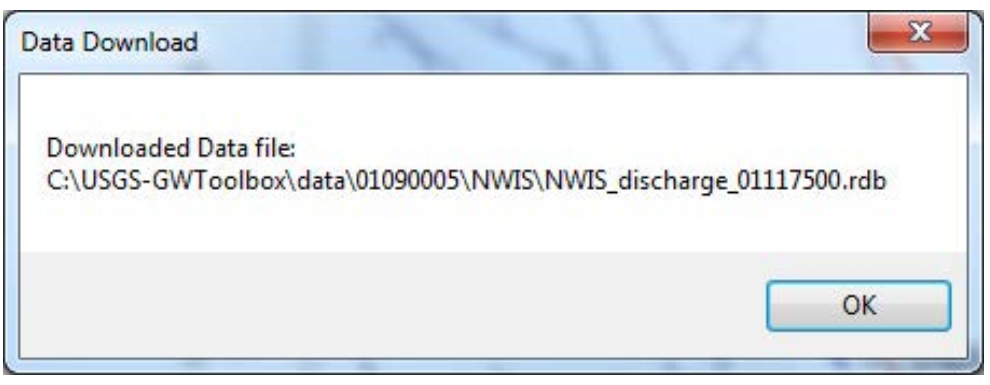

Figure 7. Dialog boxes used to retrieve data from the U.S. Geological Survey National Water Information System and other sources for use in the Groundwater Toolbox. A, The "Download Data" dialog box used to retrieve streamflow (discharge) data. $B$, The dialog box indicating that the data for the site of interest (01117500) have been retrieved and are available for use. 
are shown in red on the graph; they are difficult to identify on the graph because of the very short period of provisional data for this example. It is important to note that many of the basic computations in the GW Toolbox use data-including provisional data - for the entire period of record as the default option for the computations (such as determination of mean streamflow). The user can remove the provisional data from the computations by toggling off the "Include Provisional Data" button on the "Select Data" dialog box, or by changing the end date in the "Dates to Include" section of the "Select Data" dialog box (fig. 8A). The user can determine the exact date range of the provisional data with the "List" tool (under the "Analysis" menu option). Within the "Time Series List" dialog box, the user selects the "Value Attributes" option under the "View" option. This action adds several columns to the "Time Series List" dialog box, including the " $A$ " (for approved) and "P" (for provisional) columns. Data identified as "True" (or "Tr+") in the "P" column are provisional.

The time-series graph and flow-duration plot (fig. 9) indicate that streamflow at the streamgage is characteristic of streams that have groundwater discharge (base flow) as a primary source of water. These characteristics include perennial flow throughout the measurement period (with a minimum value of 15 cubic feet per second $\left[\mathrm{ft}^{3} / \mathrm{s}\right]$ on October 11, 1947) and a flow exceedance that is greater than about $22 \mathrm{ft}^{3} / \mathrm{s}$ more than 99.8 percent of the time (fig. 9B).

\section{Meteorological Data}

The GW Toolbox contains several types of meteorological data that can be useful in the analysis of hydrologic conditions and water budgets for a basin. The primary source of meteorological data is the BASINS 4.0 meteorological database, which is derived from data acquired from the NOAA NCDC. The database contains data for more than 16,000 weather stations through 2009, although not all stations are still active and most stations contain only a subset of the seven meteorological data types that are provided: precipitation, air temperature, wind speed, cloud cover, potential evapotranspiration, solar radiation, and dewpoint temperature. Typically, for a high-quality station, data extend from 1948 through 2005. A full description of the datasets that are available and how they were processed for the BASINS 4.0 database is provided in the online documentation. Short descriptions of the datasets used for the analyses described in this report are provided below; these datasets are a subset of the full suite of datasets available in the GW Toolbox.

A shapefile of the locations of weather stations in a project area can be downloaded by use of the "Download Data" option by selecting the "Hydrologic Units" option in the "Region to Download" panel and the "Met Stations" button under the "BASINS" section of the dialog box. Once the locations are shown on the map, the user can select the weather stations of interest with the "Select" tool and then retrieve the data for the selected stations by use of the "Download Data" dialog box (by selecting the "Hydrologic Units" option in the "Region to Download" panel and the "Met Data" button under "BASINS" section of the dialog box). A "Met Data Processing Options" dialog box will appear, and the user can select "Add individual files (one per station) to project" button, which then makes the data available for use.

For this example, data from the Kingston, R.I., weather station (station RI374266) were downloaded because the station is within the example basin. The download resulted in the retrieval of six datasets, PRCP, PREC, TMAX, TMIN, ATEM, and PEVT, which are described as follows:

- PRCP: Observed daily precipitation (in inches) from the "Cooperative Summary of the Day" NCDC source,

- PREC: Computed hourly precipitation (in inches) from the "Hourly Precipitation disaggregated from Daily" NCDC source,

- TMAX, TMIN: Observed daily maximum and minimum air temperatures, respectively, (in degrees Fahrenheit) from the "Cooperative Summary of the Day" NCDC source,

- ATEM: Computed hourly air temperature (in degrees Fahrenheit),

- PEVT: Computed hourly potential evapotranspiration (in inches) by use of the methods described in Hamon (1961).

Summary statistics provided in the "Data Tree" option from the "Analysis" menu indicate the following long-term (1971-2000) values for precipitation, air temperature, and potential evapotranspiration at the Kingston weather station: mean daily precipitation (PRCP), 0.14188 inch (in.) (or 51.82 inches per year [in/yr]); mean daily air temperature (ATEM), 49.59 degrees Fahrenheit $\left({ }^{\circ} \mathrm{F} ; 9.77\right.$ degrees Celsius $\left[{ }^{\circ} \mathrm{C}\right]$ ); mean daily maximum air temperature (TMAX), 60.73 ${ }^{\circ} \mathrm{F}\left(15.96{ }^{\circ} \mathrm{C}\right)$; mean daily minimum air temperature (TMIN), $39.38^{\circ} \mathrm{F}\left(4.10^{\circ} \mathrm{C}\right)$; and mean hourly potential evapotranspiration (PEVT) of 0.0029034 in. (or $25.45 \mathrm{in} / \mathrm{yr}$ ).

The GW Toolbox also provides a second source of precipitation data, which is available from the USGS NWIS database (USGS NWIS parameter code 00045). The locations of sites with precipitation data from NWIS can be added to a project map using the "Download Data" option in the "File" menu and by selecting "Precipitation" button under the "Station Locations from US Geological Survey National Water Information System" section. USGS precipitation collection sites are sparsely distributed and, in fact, none were found near the Pawcatuck River Basin. 


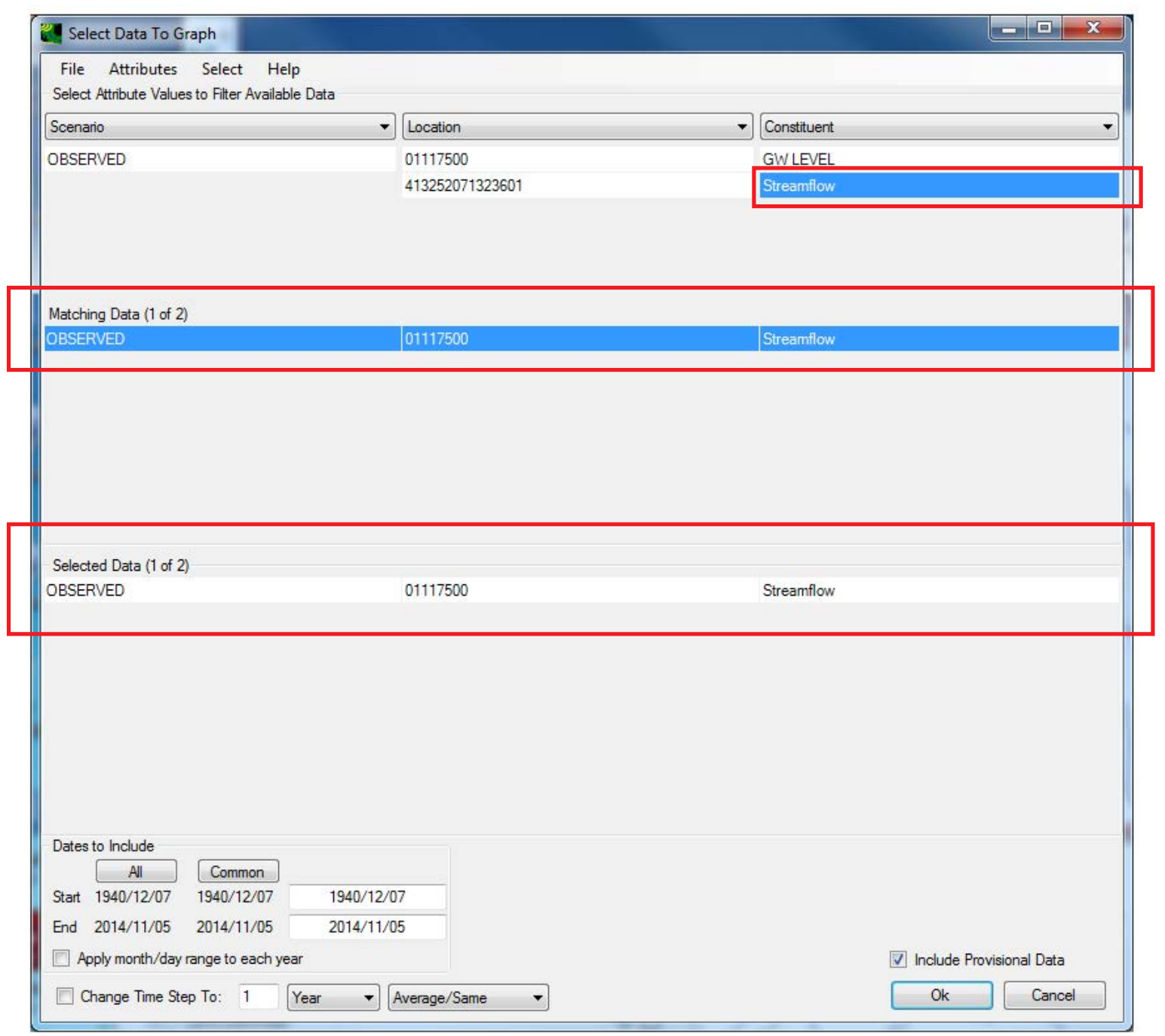

Step 1

Step 2

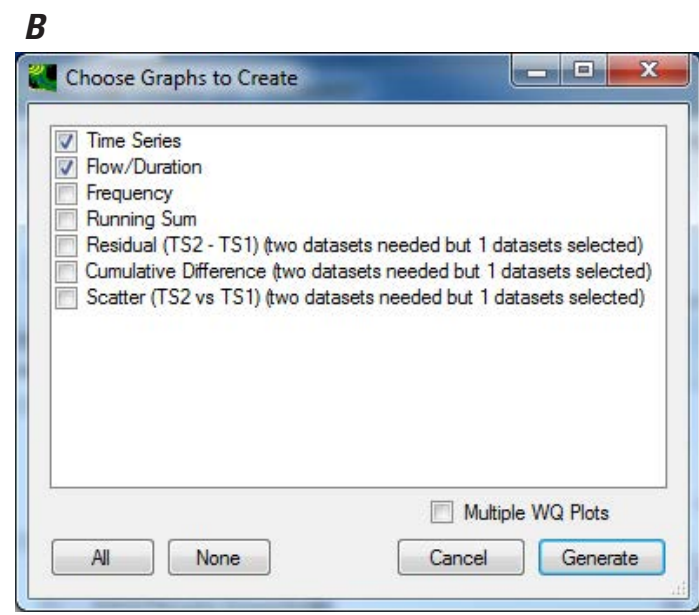

Figure 8. Dialog boxes used to select and graph data for use in the Groundwater Toolbox. $A$, The "Select Data to Graph" dialog box for selecting time-series data to graph. $B$, The "Choose Graphs to Create" dialog box to select graph types. Steps are described in the text. 
A

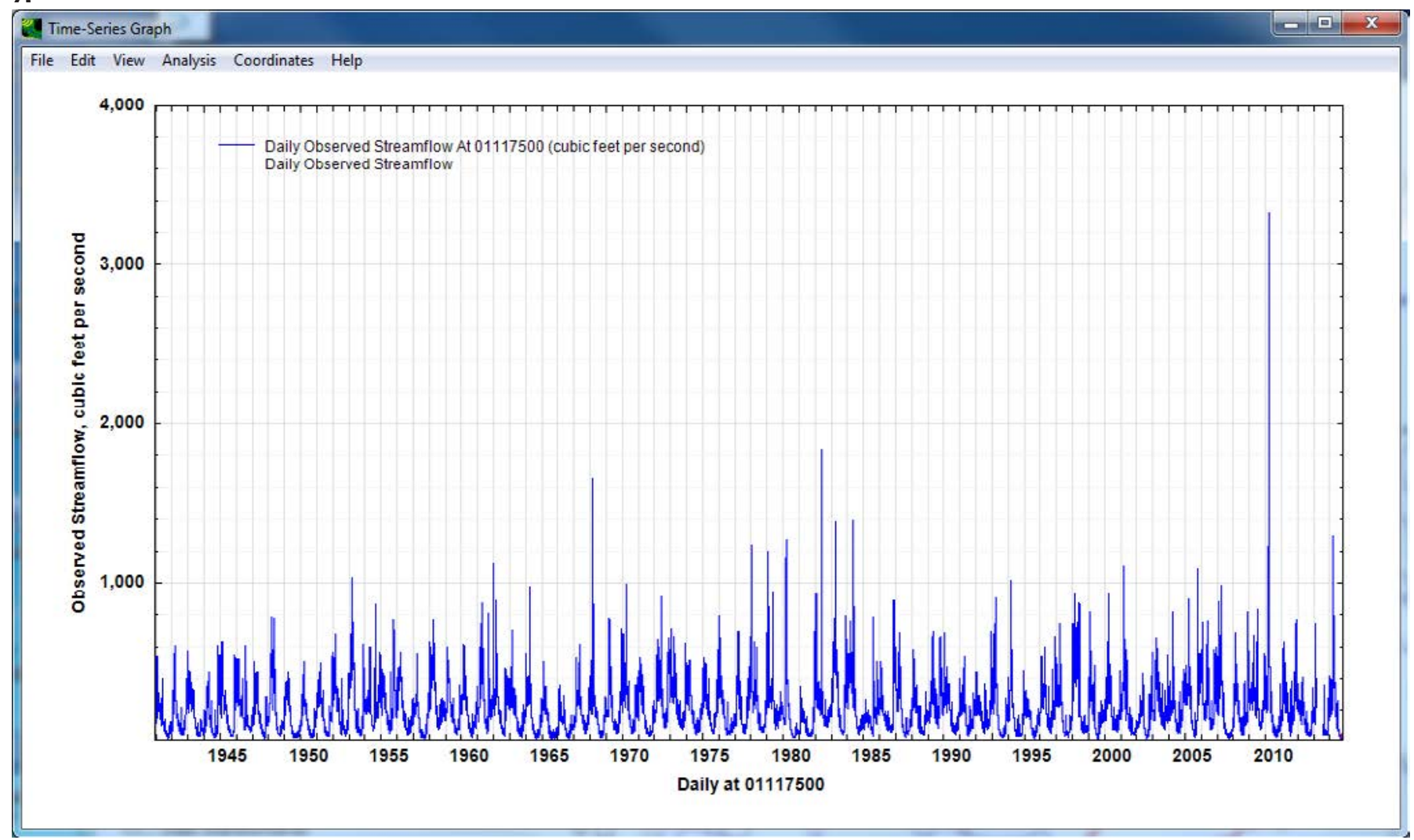

$\boldsymbol{B}$

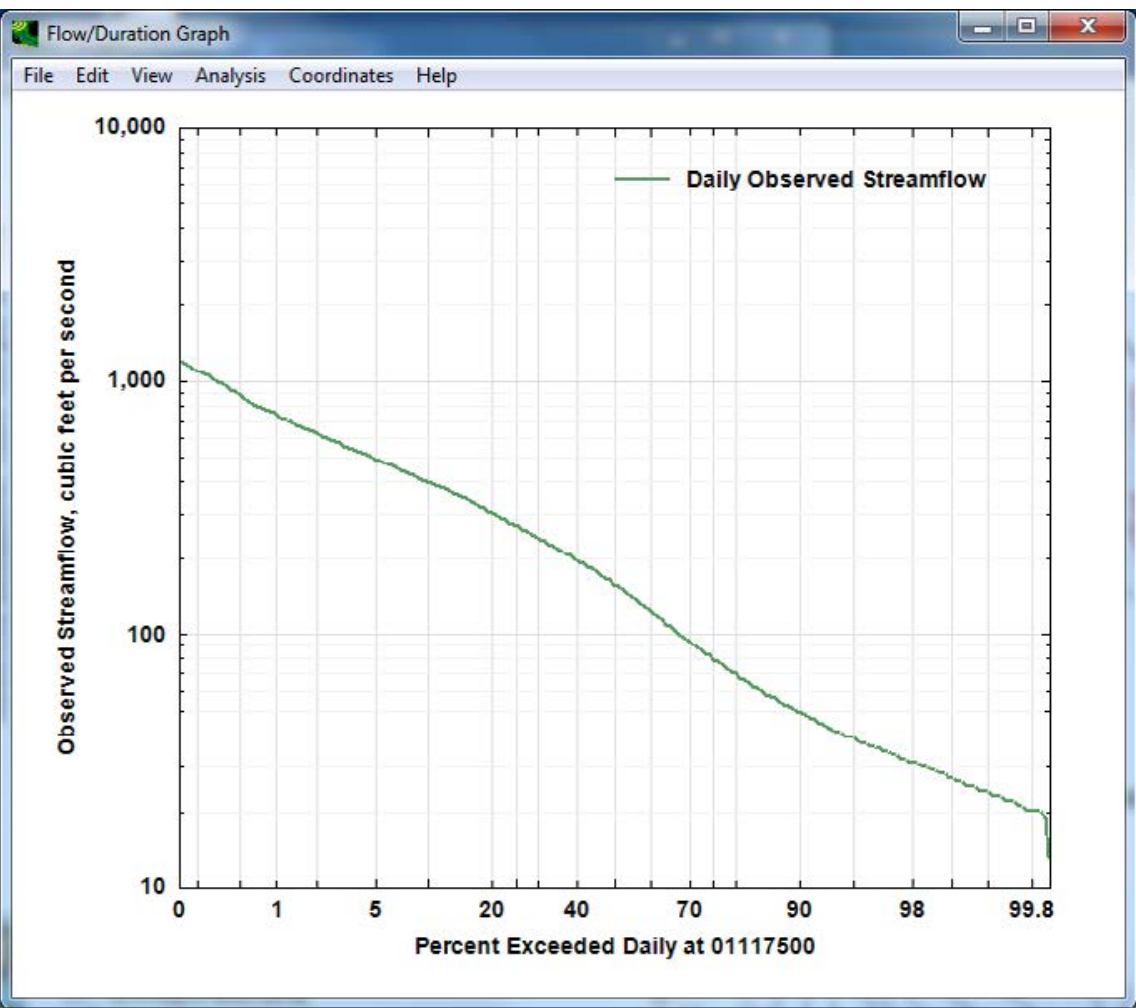

Figure 9. Graphs of streamflow data at the example streamgage on the Pawcatuck River at Wood River Junction, Rhode Island, for use in the Groundwater Toolbox. $A$, Streamflow hydrograph. $B$, Flowduration curve. 


\section{Base-Flow and Runoff Components of Streamflow: Hydrograph Separation}

The base-flow and runoff components of streamflow are determined by use of the "USGS Base-Flow Separation" option in the "Analysis" menu. This menu option brings up the dialog box "Select Daily Streamflow for Analysis," which is similar to the "Select Data to Graph" dialog box described previously and shown in figure $8 \mathrm{~A}$. The user selects a single streamflow dataset from the list of available datasets for analysis; in this example, data for site 01117500 were selected. Selection of a dataset will result in the "Base-Flow Separation" dialog box shown in figure 10A.

The user selects one or more of the six available hydrograph-separation methods. If the BFI-Standard or BFI-Modified methods are selected, the GW Toolbox will populate the "BFI Parameters" panel of the dialog box with default values: a partition length $(N)$ of 5 days, a turning point test factor $(f)$ of 0.9 , and (or) a recession constant $\left(K^{\prime}\right)$ of 0.97915 . Also, for the BFI options, the user can specify that results will be written to the original BFI output files by "Calendar Year" or "Water Year." This option is only available for the BFI programs. If the drainage area to the streamgage is available as an attribute with the NWIS streamflow data, the GW Toolbox will automatically populate the panel with that value, as shown for the Pawcatuck River streamgage $\left(100 \mathrm{mi}^{2}\right)$; however, the user can modify the drainage-area value as desired.

The user then defines the dates for analysis. The "Examine Data" button can be used to determine which months have complete records (fig. 10B); the "Examine Data" utility was originally released with the PART software distribution as the "screen" program. If "Water Year" has been selected for the BFI options, the user should specify that the analysis begins on October 1 of the year preceding the first water year of interest and ends on September 30 of the last water year of interest. For example, if the user is interested in water years 1938 through 1945, “Analysis Dates" of 1937/10/01 through 1945/09/30 would be specified. Complete years of record are available for the Pawcatuck River streamgage between 1941 and 2012, but only 1971 through 2000 will be analyzed in the example (fig. 10A), for consistency with the available meteorological data.

Many output files will be created by running the hydrograph-separation programs, and these should be saved in a directory that is specified in the "Text Output" section of the dialog box. Each file will have a base name or prefix that also is specified in this section of the dialog box. After specifying the output directory, the user clicks the "Run Base-Flow Separation Program(s)" button to run the programs. If all six methods have been selected, there can be a pause of several seconds while the programs complete their calculations. When completed, a dialog box will appear that says "Base flow output completed."

The user can now examine the output files or graph the results of the programs. Inspection of the several files in the output directory indicates that the GW Toolbox creates not only the original output files generated by each of the individual programs but also several comma-delimited (.csv) output files that include results of all methods selected for analysis. These comma-delimited files include output at daily, monthly, and annual (by calendar year) time intervals for the period of analysis; there also is a duration.csv file that gives the percentage of time that each streamflow, base-flow, or surfacerunoff value was equaled or exceeded. Unlike some previous versions of the original programs, the PART, HYSEP, and BFI methods implemented in the GW Toolbox can be used to calculate base flow and runoff for periods of record that span only part of a full calendar year; however, if the dates defined for the analysis span only part of a particular month or calendar year, results in the monthly.csv and yearly.csv files will not include the partial months or years.

Several graphing options also are available in the "Display Graph" panel to review the hydrograph-separation results. A particularly useful option is "Flow Duration," which creates flow-duration graphs of the observed streamflow and calculated base-flow and runoff results for each method. The flow-duration graphs for the Pawcatuck River streamgage indicate that base flow is the predominant source of water to the river at nearly all flow-duration levels. The graphs also demonstrate a fair amount of variability in the hydrograph-separation results, particularly at the highest streamflows (fig. 11). The PART method generates the highest base-flow estimates throughout the range of flows, whereas the two BFI methods generate the lowest estimates. These general results, however, do not represent all streamgages; for example, several initial tests with the GW Toolbox with data from streamgages across the United States indicated that the methods that yield the highest and lowest values of base flow varied among streamgages.

Average annual rates of streamflow, base flow, and runoff can be calculated with a spreadsheet program from results listed in the yearly.csv file. For the 30-year period evaluated here, the average-annual rate of streamflow at the Pawcatuck River streamgage was $204 \mathrm{ft}^{3} / \mathrm{s}$, or $27.7 \mathrm{in}$. over the basin. Calculated rates of average annual base flow for the 30 -year period range from minimums of 20.8 and $21.0 \mathrm{in}$., calculated by the two BFI methods, to a maximum of $24.9 \mathrm{in}$., calculated by the PART method; the mean of the six average annual values is $22.8 \mathrm{in}$. Average annual runoff ranges from a minimum of $2.8 \mathrm{in}$. for the PART method to 6.7 and $6.9 \mathrm{in}$. for the two BFI methods, with a mean of the six values of 4.9 in. The value of base flow at the streamgage calculated by the PART method is close to that reported by Bent and others (2011) for the 63-year period from 1942 through 2004 (23.9 in.), which was determined by use of the original PART program (Rutledge, 1998). 
$\boldsymbol{A}$

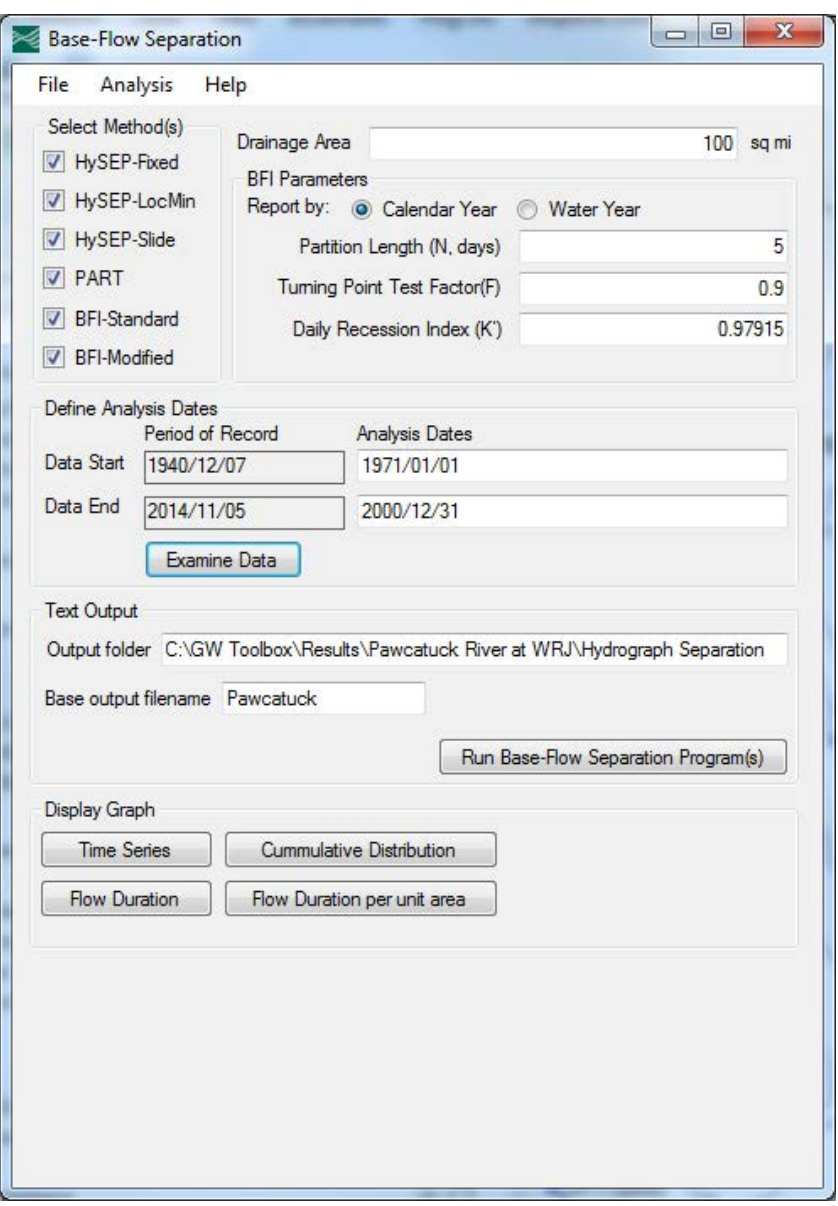

$B$

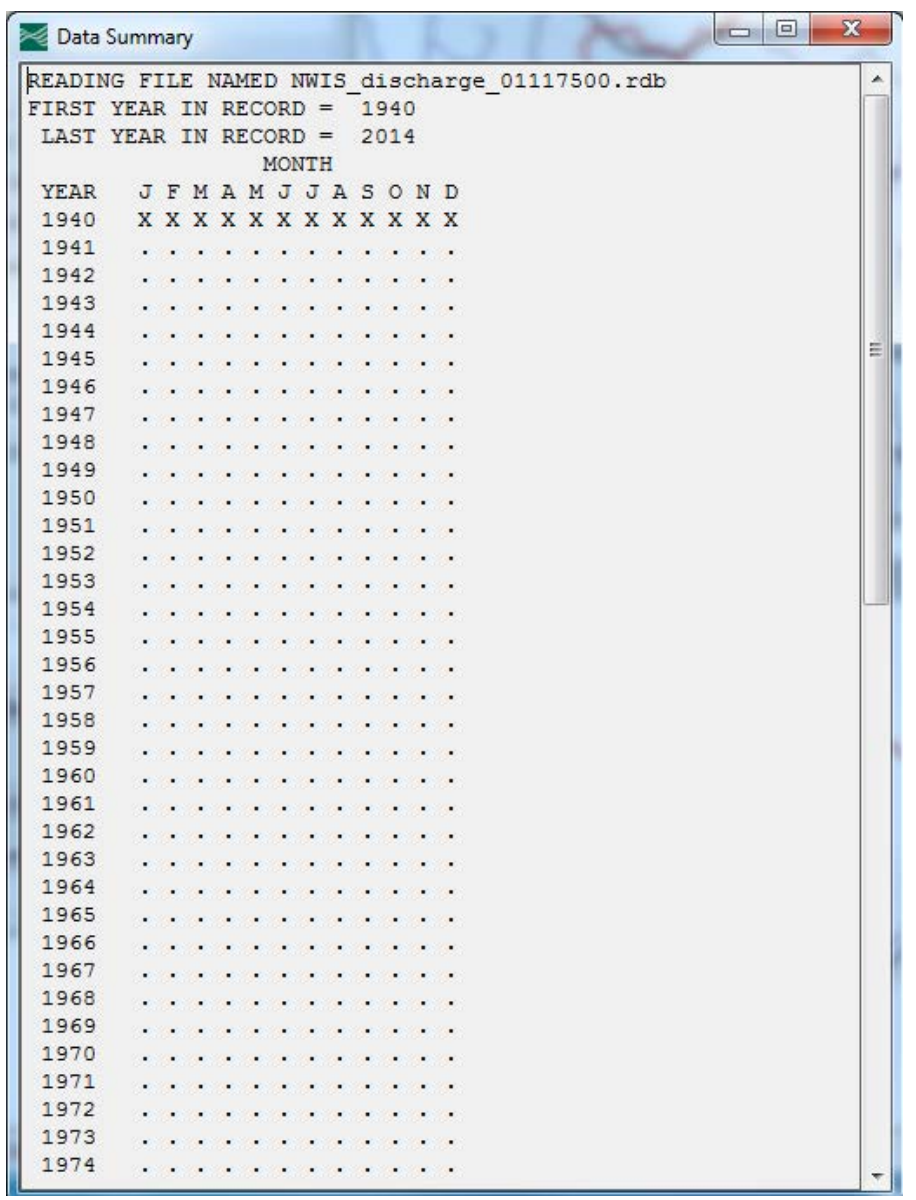

Figure 10. Dialog boxes used in the base-flow separation analysis component of the Groundwater Toolbox. $A$, The "Base-Flow Separation" dialog box. B, Part of the "Data Summary" dialog box, which shows months having complete (dots) or incomplete (Xs) records.

\section{Groundwater Recharge}

Groundwater recharge is calculated by the RORA recession-curve displacement method (Rutledge, 1998). As described previously, the RORA program requires that a recession index be specified for the basin. This index can be determined independently from the GW Toolbox or can be estimated by use of the RECESS program (Rutledge, 1998), which is included in the GW Toolbox. The RECESS and RORA methods are invoked with the "USGS RECESS" and "USGS RORA" options under the "Analysis" menu. Each of these menu options brings up the dialog box "Select Daily Streamflow for Analysis," which is similar to the "Select Data to Graph" dialog box described previously and shown in figure 8A. The user selects a single streamflow dataset from the list of available datasets for analysis; in this example, data for streamgage 01117500 were selected. The sections below describe details for each analysis method.

\section{RECESS Program To Estimate Basin Recession Index}

The RECESS program can be used to estimate a median value of the recession index $(K)$, which is needed by the RORA program, as well as to perform several other functions that are described in detail by Rutledge (1998). The user is encouraged to read the sections of Rutledge (1998) concerning RECESS; the description here is intended to illustrate how RECESS has been implemented in the GW Toolbox. Selection of a streamflow dataset in "Select Daily Streamflow for Analysis" dialog box, accessed through the "USGS RECESS" option of the "Analysis" menu, will bring up the "USGS RECESS" dialog box shown in figure 12A.

The first step is to select the dates for which streamflow recessions will be analyzed. These dates need not coincide with the time period used in the hydrograph-separation or recharge analyses, although, for this example, coincident dates are specified (fig. 12A, "Analysis Dates" entries). The user also specifies an output directory for the RECESS results. 


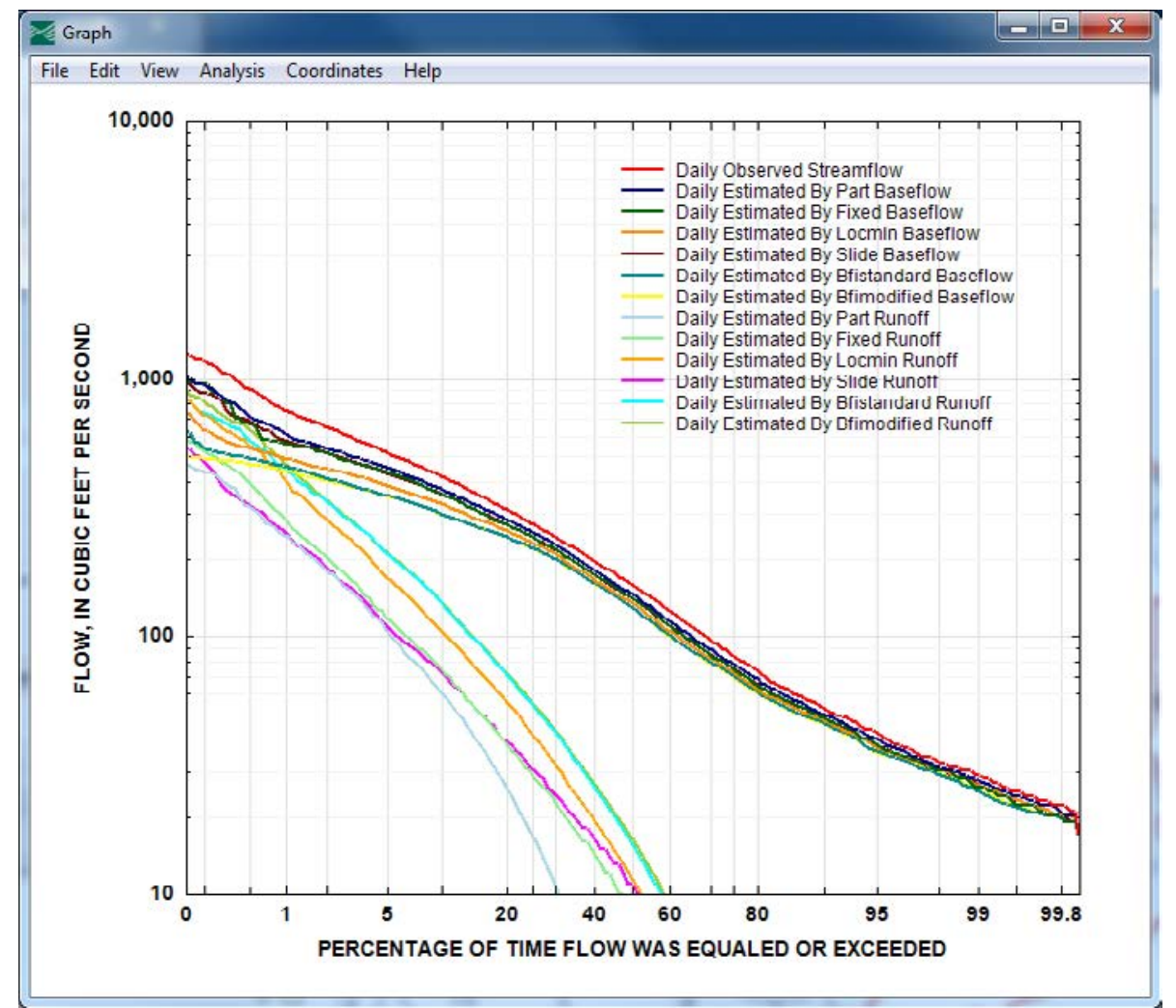

Figure 11. The flow-duration curves for measured streamflow and estimated base flow and runoff for the Pawcatuck River at Wood River Junction, Rhode Island, from 1971 through 2000 using the six hydrograph-separation methods available in the Groundwater Toolbox.
The user then specifies the "Months and Seasons" for which recession periods will be analyzed; the program will select only those recession periods that begin in the selected months. For this analysis, only the four winter months from December through March were selected for analysis, because it is assumed that riparian evapotranspiration is negligible during these months. Riparian evapotranspiration can create nonlinearity in a recession graph of the logarithm of streamflow as a function of time. The "Winter" radio button also has been selected to coincide with the four selected months; selection of a season is used only to insert a text entry in the output files and does not affect the results.

Finally, the user specifies the minimum number of days required for detection of a recession period. Rutledge (1998) notes that if the number of days selected is too large (too restrictive), few recession periods will be detected in the record; however, if the number is too small, then many recession periods will be detected and some may need to be omitted, because they would not span a recession period long enough for the user to derive an accurate value of $K$. Rutledge (1998) suggests a minimum of 10 to 20 days when analyzing a record of 40 years. Values of 10 and 15 days were tested for this example; a total of 61 recession periods were identified for the streamflow record from 1971 through 2000 for the 10-day minimum requirement and only 17 recession periods were detected for the 15-day minimum requirement. Results for the 15-day requirement are illustrated here.

The user then clicks the "Find Peaks" button (fig. 12A), which brings up the list of recession periods that fit the minimum requirement of days of recession following a streamflow peak (fig. 12B). For this example, 17 recession periods are listed, the first having had a peak streamflow on January 7, 1971. Clicking on the date ("1971/ 1/ 7" in this example) brings up a list of the streamflows during this recession period, beginning one day after the peak (January 8) and continuing for 15 days (through January 22) until the next increase in streamflow on January 23. A semilogarithmic plot of the streamflow data is shown on the right of the dialog box.

The user can now either "Analyze" the streamflow data for the full recession period or eliminate some of the data if any part of the recession graph looks nonlinear. For this example, both approaches are illustrated. First, by clicking "Analyze" with all data selected, a recession index ("DAYS/LOG CYCLE") of 38.432305 is calculated by RECESS (fig. 12C). In the second approach, the user may limit the analysis to periods of the recession that are nearly linear on the semilogarithmic plot. Rorabaugh (1964) and Rutledge (1998) note that the slope of the semilogarithmic recession graph, which is equal to the value of $K$, should be linear after a "critical time" $\left(t_{c}\right)$. This critical time, which is a function of the properties of the groundwater system (Rorabaugh, 1964; Rutledge, 1998), should be a constant value that is independent of any particular recession period selected for analysis. In practice, however, the apparent value of $t_{c}$ may vary from one recession period to another. For example, for the recession period January $8-22,1971$, the recession graph indicates there is a period of slight nonlinearity during approximately the first 4 days of recession. The user might conclude, therefore, that $t_{c}$ equals 
$\boldsymbol{A}$

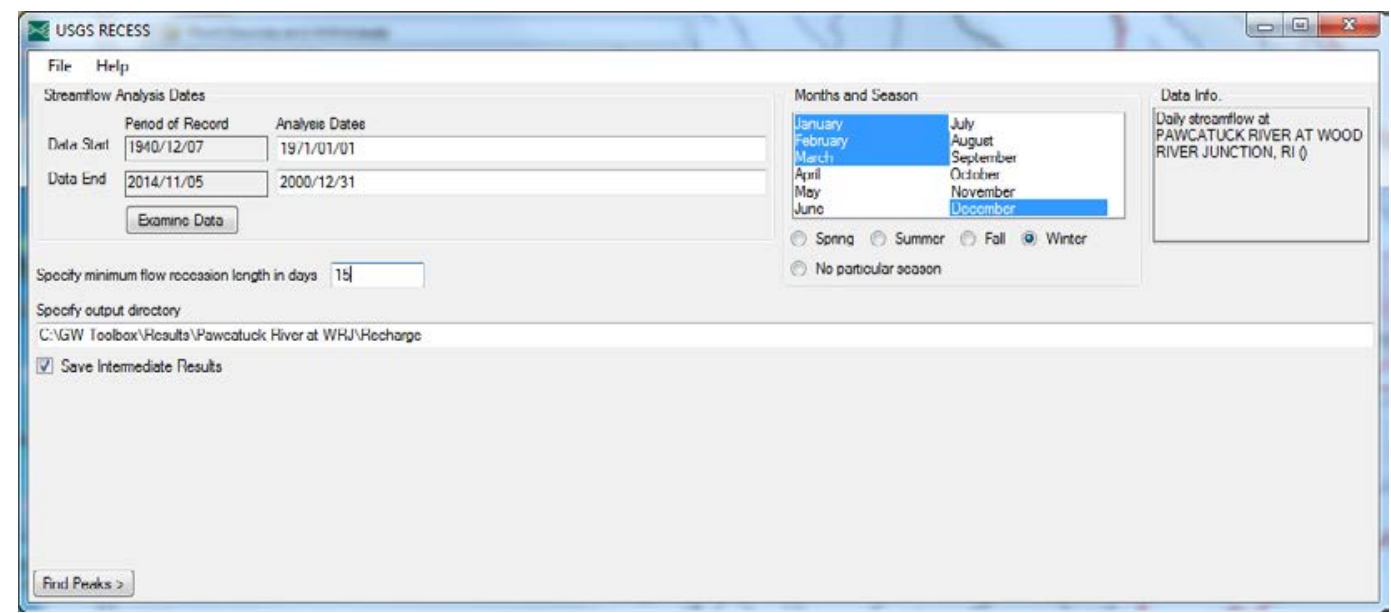

B

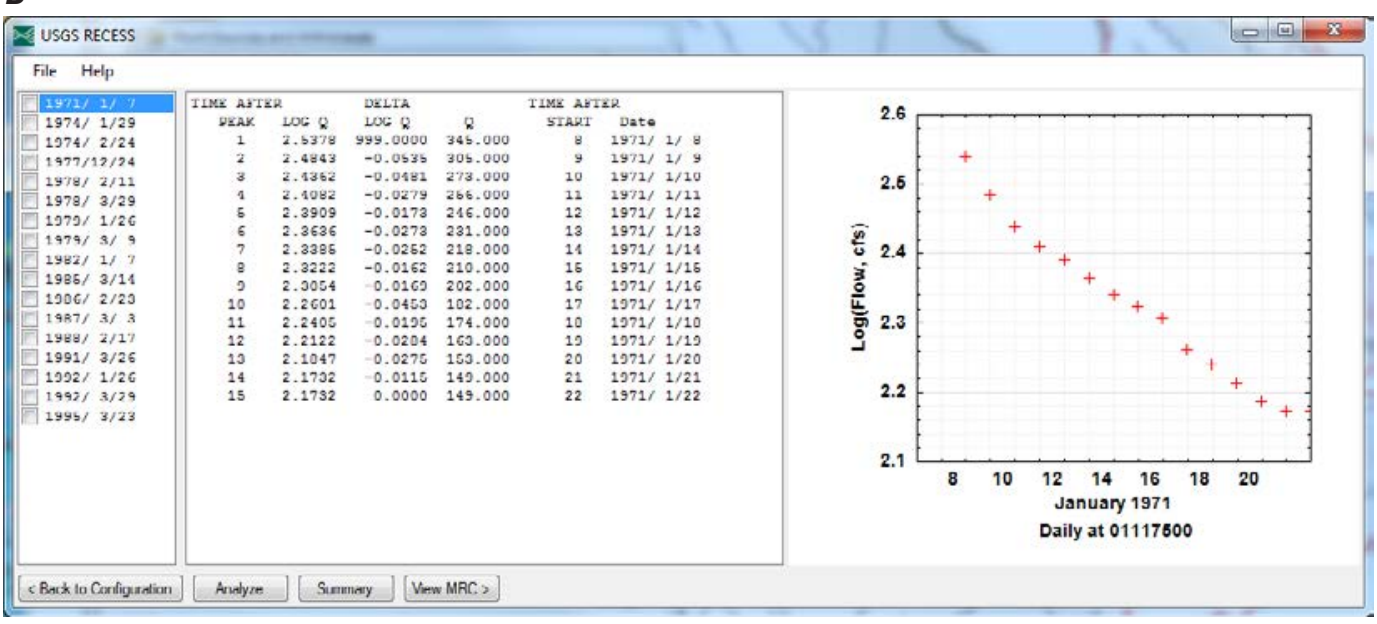

C

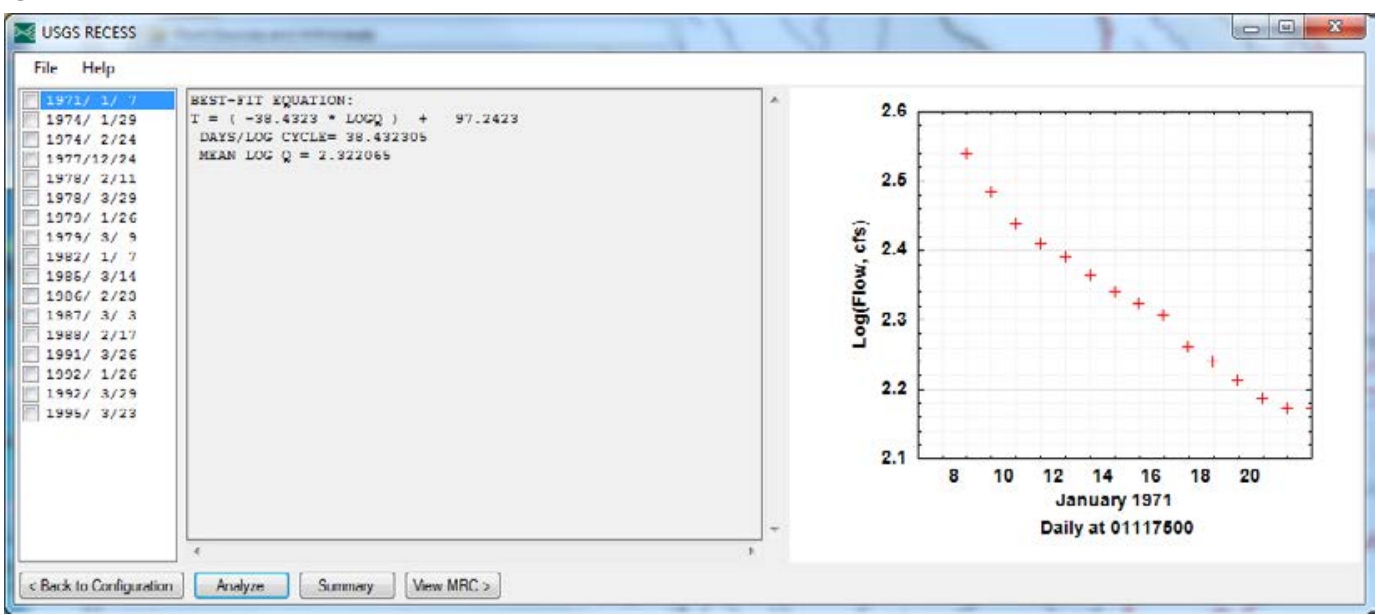

Figure 12. Dialog boxes used for the RECESS component of the Groundwater Toolbox. $A$, Initial dialog box to specify the dates, months, and seasons for analysis, the minimum number of days required for detection of a recession period, and the output directory. $B$, Dialog box showing recession periods that meet the minimum-day requirement (left side of dialog box), the first recession period beginning after a peak streamflow on January 7, 1971 (middle part of dialog box), and a semilogarithmic graph of the first recession period (right side of dialog box). C, Dialog box showing the estimated recession index of 38.432305 days per log cycle for full period of recession from January 8 through January 22, 1971. 


\section{D}

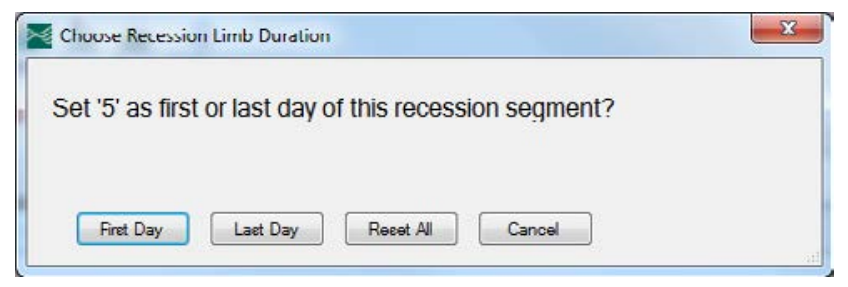

\section{$\boldsymbol{E}$}

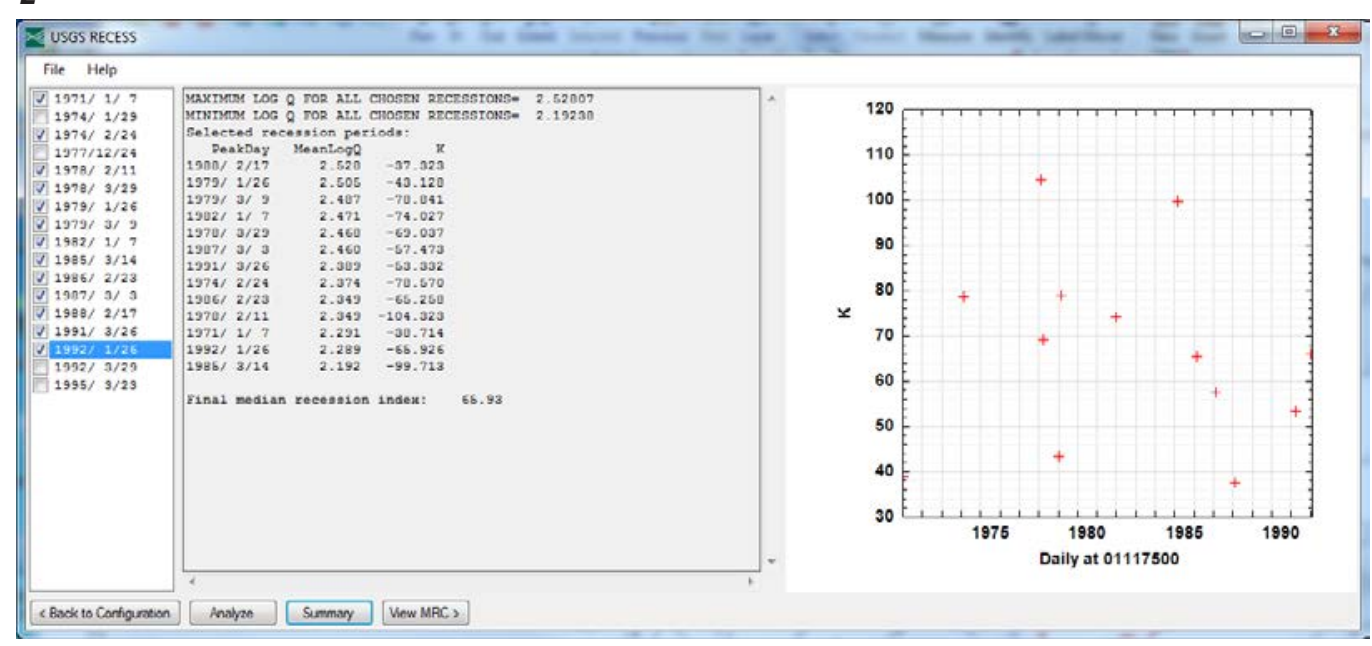

Figure 12. Dialog boxes used for the RECESS component of the Groundwater Toolbox. D, The "Choose Recession Limb Duration" dialog box allows the user to refine the days that will be used to calculate the recession index. E, Dialog box showing a summary, the median value, and a scatter plot of the recession indices calculated by RECESS for the example basin.-Continued

4 days for this particular recession period, and then select the period January 12-20, 1971, for analysis. This is done by first clicking on the row of data identified as day 5 after the peak streamflow (fig. 12B), which brings up the "Choose Recession Limb Duration" dialog box (fig. 12D). The user then selects " 5 " as the "First Day" of analysis. This action restricts the number of days that will be analyzed to days 5 through 15 . The data-reduction process can be repeated to eliminate data after day 13 that appear to diverge from the straight-line segment of the recession. This is done by selecting the row of data identified as day 13 after the peak streamflow and then selecting "13" as the "Last Day" of analysis in the "Choose Recession Limb Duration" dialog box; this further restricts the number of days that will be analyzed to days 5 through 13 . With these days selected, a slightly higher recession index of 38.713915 was calculated for this 9-day period (not shown on figure 12). Selecting the check box next to the start date of the recession period (that is, to the left of " $1971 / 1 / 7$ ") will save the recession index for later use (fig. 12E).

After analyzing several periods of recession using the same process, the user can then click the "Summary" button to summarize the values of all recession indices calculated during the analysis (fig. 12E). For this example, varying lengths of recession periods were analyzed for 13 recessions selected during the record for 1971 through 2000. For these 13 recession periods, the first day of analysis ranged from 5 to 7 ; that is, $t_{c}$ was determined to range from 4 to 6 for the 13 recession periods. In most cases, this number of recession periods would be too few for a formal analysis, but is sufficient for this example. Rutledge (1998) suggests that 20 to 30 periods of recession might be used for a typical analysis; Rutledge and Mesko (1996, table 2) analyzed from 6 to 49 recession periods for 157 streamflow records in a study of streamflow recession and base flow in the Appalachian Valley and Ridge, Blue Ridge, and Piedmont Physiographic Provinces that extend from Pennsylvania southward into Alabama. The summary listing of the 13 calculated recession indices is given in the middle panel of the dialog box and a graph of the indices (by date) is given on the right side of the dialog box. The median recession index calculated for the 13 recession periods is 65.93 days per log cycle, but, as seen in figure $12 \mathrm{E}$, there is a range of calculated values distributed about this median value that extends from a minimum of 37.323 days per log cycle to a maximum of 104.323 days per log cycle (fig. 12E). The user can remove one or more of the calculated recession indices from the summary listing by unchecking their corresponding dates of peak streamflow on the left side of the dialog box and clicking again on the "Summary" button. For example, if the recession index of 104.323 days per log cycle calculated for the period following the "1978/2/11" peak is removed, a new, slightly lower, median recession index of 65.59 days per $\log$ cycle is calculated for the remaining 12 recession periods. 
Each time the "Summary" button is clicked, the median value of the recession index will be written to the index.txt file in the output directory.

\section{RORA Program To Estimate Groundwater Recharge}

The RORA program is accessed through the "USGS RORA" option from the "Analysis" menu. As on the "BaseFlow Separation" dialog box, the user selects a period of analysis and an output directory (folder) and base name (prefix) for the output file on the "USGS RORA" dialog box (fig. 13). The drainage area of the basin is automatically loaded into the RORA dialog box if it is available from the downloaded NWIS data. Also, if the RECESS program has been run to determine a recession index for the basin in the same $\mathrm{GW}$ Toolbox session, then the final estimate of the median recession index will be loaded automatically into the RORA dialog box. Alternatively, the "Browse Recession Index" button can be used to navigate to a directory in which the index.txt file, which holds values of the median recession indices calculated by the RECESS program, can be opened and a specific recession index identified for use in the RORA analysis. Values of the drainage area and recession index that have been loaded automatically can be changed by the user if desired.

The program also automatically calculates the value of the antecedent-recession requirement, which is equivalent to the duration of surface runoff for the basin $\left(N_{s r}\right.$, in days; see the "Base-flow, Runoff, and Recharge Estimation Methods and Applicability" section). The default value of the antecedentrecession requirement can be modified by the user. If the streamflow record includes zeros, the program will replace the zeros with the default value of $0.01 \mathrm{ft}^{3} / \mathrm{s}$ (which can be modified by the user), so that extrapolation done by the program on the $\log$ scale is possible.

After each section of the dialog box has been completed, the user can click on either the "Plot Monthly Recharge" or the "Write ASCII Outputs" button to run the RORA program. Clicking on the latter button creates several files in the output directory; these files include those generated by the original RORA program (Rutledge, 1998) and two comma-delimited data files that hold the monthly (roramon.csv) and annual (roraAnn.csv) recharge rates calculated by RORA (in inches over the basin). An average annual recharge rate for the 30-year period evaluated here for the example basin was calculated to be 26.6 in. with a spreadsheet program from the results listed in the Pawcatuck_roraAnn.csv file. This value of basin-wide recharge is similar to that calculated by Bent and others (2011) by use of streamflow data at the streamgage for the 63-year period from 1942 through 2004 (25.9 in.) determined by use of the original RECESS and RORA programs (Rutledge, 1998). The monthly recharge rates calculated for the analysis period are shown in figure 14.

Although the RORA method is based on the assumption that the value of the recession index is constant throughout a basin, in practice, as the example showed, there can be substantial variability in the values calculated from a streamflow record. Rutledge (1998), however, has shown that the results of RORA are only slightly sensitive to variation in the value specified for the index. This sensitivity is illustrated by varying the value of the recession index estimated for the analysis of the Pawcatuck River streamflow data by \pm 50 percent. In the first sensitivity test, the recession index was decreased to a value of 32.80 days per log cycle. The resulting average annual recharge rate for the 30 -year period increased by 0.40 in. (from 26.64 to 27.04 in.), an increase of only 1.5 percent above the base value. In the second test, the recession index was increased to a value of 98.39 days per log cycle. The resulting average annual recharge rate decreased by $0.67 \mathrm{in}$. (to 25.97 in.), a decrease of 2.5 percent below the base value. These results indicate that, although the value of the recession index may be quite variable - as was the case for the Pawcatuck River Basin estimates - the user should not spend an inordinate amount of time attempting to refine the estimates of the recession index calculated with the RECESS program.

\section{Water Budgets for the Example Basin}

Water budgets are an important tool for evaluating and managing the availability and sustainability of water supplies for a particular basin (Healy and others, 2007). As demonstrated in previous sections of the report, the GW Toolbox provides methods to quantify several components of a basinwide water budget, such as base flow, runoff, and groundwater recharge. This section illustrates how the GW Toolbox can be used to quantify several additional water-budget components for a basin, and then demonstrates how these individual waterbudget components can be used to determine an estimate of basinwide, long-term average water budgets. The approach taken here is similar in several ways to that described by Rutledge and Mesko (1996) for water budgets determined for basins in the Appalachian Valley and Ridge, Blue Ridge, and Piedmont Physiographic Provinces. These methods are demonstrated here for the Pawcatuck River Basin at the Wood River Junction streamgage for the 30-year period from 1971 through 2000. A summary of the methods used to estimate each water-budget component, as well as the values estimated, is provided in table 1 .

A water budget accounts for all of the inflows, outflows, and changes in storage of water throughout a basin. For the Pawcatuck River Basin, components of the water budget that may need to be quantified are precipitation, streamflow into and out of the basin, groundwater underflow into and out of the basin, water-use transfers into and out of the basin, evapotranspiration, and changes in water storage throughout the basin. The water-budget equation is written as

$$
P+\frac{S F_{i}}{A}+\frac{G W_{i}}{A}+\frac{W U_{i}}{A}=\left(\frac{S F_{o}}{A}+\frac{G W_{o}}{A}+\frac{W U_{o}}{A}+E T\right)+\Delta S,
$$




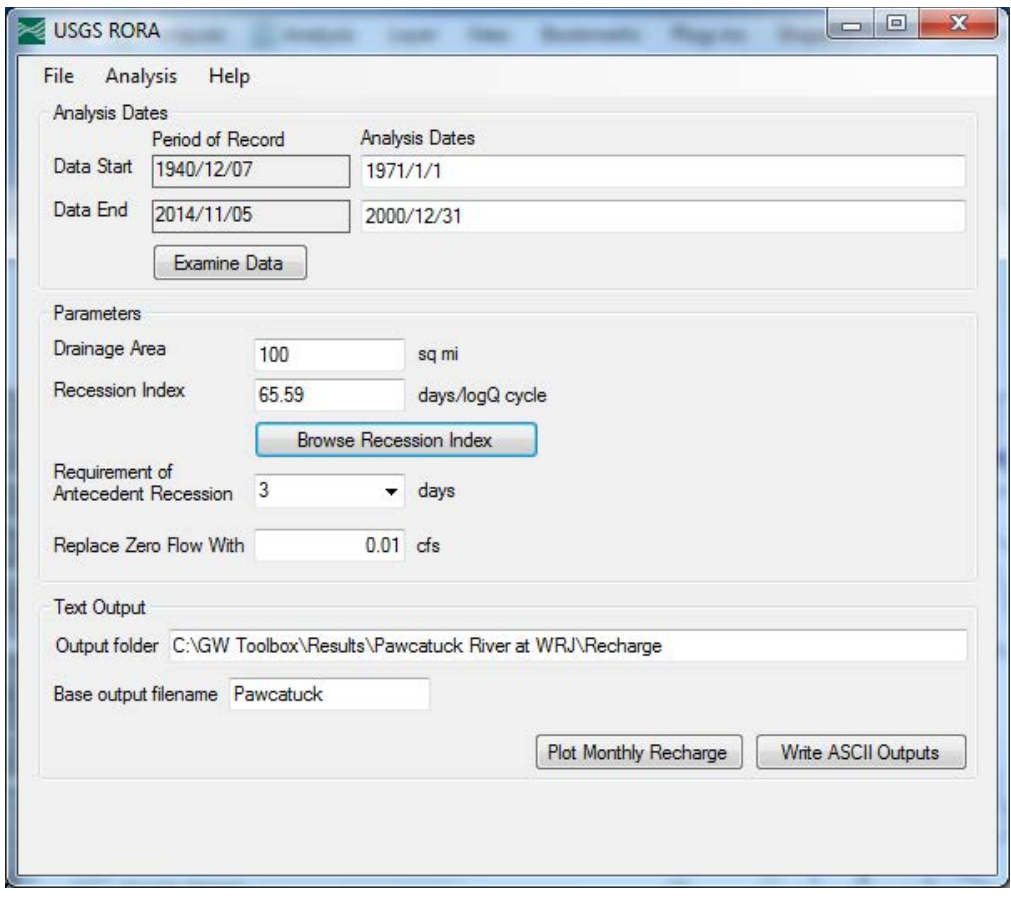

Figure 13. The "USGS RORA" dialog box to estimate groundwater recharge by use of the RORA program in the Groundwater Toolbox. where

$P \quad$ is the average annual rate of precipitation (length over time),

$S F_{i}$ and $S F_{o} \quad$ are the average annual rates of streamflow into and out of the basin (cubic length over time), respectively,

$A \quad$ is the drainage area of the basin (square length),

$G W_{i}$ and $G W_{o} \quad$ are the average annual rates of groundwater underflow into and out of the basin (cubic length over time), respectively,

$W U_{i}$ and $W U_{o}$ are the average annual rates of water transfers into and out of the basin (cubic length over time), respectively,

ET is the average annual rate of evapotranspiration from the basin (length over time), and

$\Delta S \quad$ is the total storage change in the basin (length over time).

Equation 3 is a modified version of water-balance equations presented by Healy and others (2007) and Sanford and others (2012), and reflects the authors' conceptual model of the important components of the hydrologic system at the scale of the watershed $\left(100 \mathrm{mi}^{2}\right)$ over the 30 -year analysis period. The terms on the left side of the equation are the flows into the basin, whereas those on the right are the flows out of the basin (in parentheses) and the change in water storage in the basin. It should be acknowledged that there are inherent uncertainties in the estimates of each water-budget term that reflect the accuracy by which each term can be estimated from the methods available in the GW Toolbox. These uncertainties have not been quantified, but should be recognized as being present. Thus, the right- and left-hand sides of equation 3 must be balanced by an error term, which is not shown but is implicit in the equation.

Several of the terms in equation 3 are either known to equal zero or can be assumed to equal zero for the example of the Pawcatuck River Basin. First, there is no streamflow into the basin, so that $S F_{i}$ is zero. Second, although it is known that there are small amounts of groundwater flow into and out of the basin (Bent and others, 2011), it is assumed that the surface-water and groundwater drainage areas to the streamgage are the same, so that the two groundwater-underflow terms, $G W_{i}$ and $G W_{o}$, are zero. Third, Bent and others (2011) indicate that there are relatively few internal withdrawals from either the groundwater or surface-water systems within the basin or interbasin transfers to or from adjacent basins; therefore, the two water-use transfer terms into and out of the basin, $W U_{i}$ and $W U_{o}$, can be assumed to be zero. Finally, it is assumed that during the 30-year period of analysis, the net change in water storage within the basin is zero $(\Delta S=0)$. This assumption is based on visual inspection of four groundwater-level records from observation wells within the Pawcatuck-Wood Basin that span the period of analysis (wells RI-WEW 522, RI-CHW 18, RI-SNW 6, and RI-SNW 515). These records indicate no long-term upward or downward trends in groundwater levels Therefore, equation 3 can be simplified to

$$
P=\frac{S F_{o}}{A}+E T .
$$

In this report, the units of measurement are inches per year for precipitation and evapotranspiration, cubic feet per second for streamflow, and square miles for drainage area. Appropriate conversion factors are used to convert each of these 


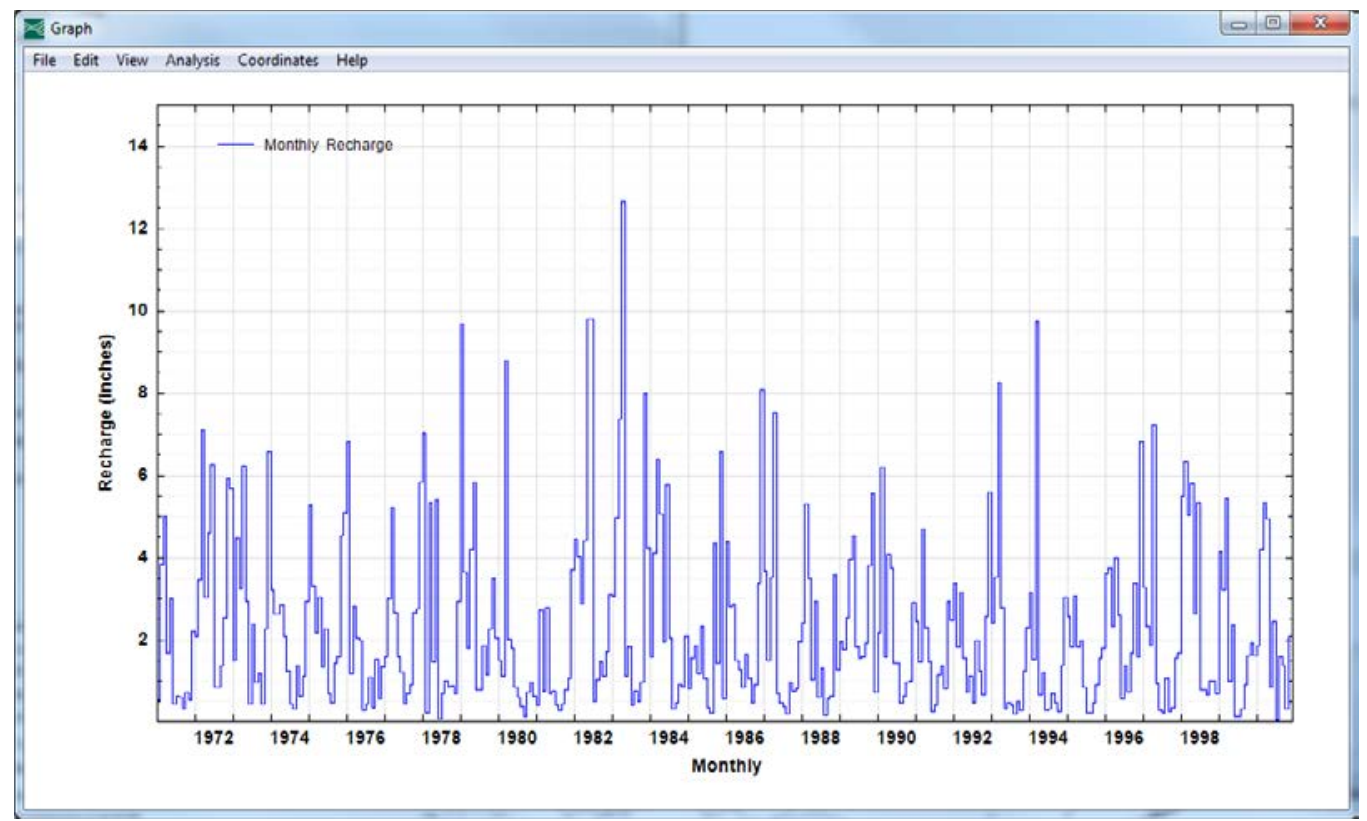

Figure 14. Graph of monthly recharge, in inches over the drainage basin, calculated by the RORA program for the Pawcatuck River Basin at Wood River Junction, Rhode Island, from January 1971 through December 2000. units to a single, consistent unit of inches per year for all water-budget terms.

Average annual rates of precipitation and streamflow for the 30-year period were shown previously to equal 51.8 and 27.7 in., respectively. Therefore, equation 4 can be used to estimate the average annual rate of evapotranspiration from the basin (24.1 in/yr), which, because it is the difference between observed precipitation and streamflow, is taken to be the actual rate of evapotranspiration from the basin. This rate differs from a potential rate of evapotranspiration, which is the rate that would occur if there was a nonlimiting supply of water. Although the GW Toolbox provides computed rates of potential evapotranspiration for many weather stations (the PEVT dataset described previously), these data are not useful for the water-budget analysis. The calculated rate of actual evapotranspiration is 46.5 percent of the average annual precipitation rate (that is, $E T / P$ ), which is very close to the value of 44.5 percent calculated by Sanford and Selnick (2012, supplemental data table S1) for the entire $295 \mathrm{mi}^{2}$ Pawcatuck River Basin for the same period.

Table 1. Water-budget components estimated for the Pawcatuck River Basin at Wood River Junction, Rhode Island from 1971 through 2000.

[All water-budget components are given in inches over the 100-square-mile drainage basin. NOAA, National Oceanic and Atmospheric Administration; NCDC, National Climatic Data Center; USGS, U.S. Geological Survey; NWIS, National Water Information System; GW, groundwater; PRCP, precipitation dataset]

\begin{tabular}{|c|c|c|}
\hline $\begin{array}{l}\text { Water-budget } \\
\text { component }\end{array}$ & Method of analysis & Value (inches) \\
\hline Precipitation & NOAA NCDC precipitation data retrieved with the GW Toolbox (PRCP dataset) & 51.8 \\
\hline Base flow & Average of the six hydrograph-separation methods provided with the GW Toolbox & 22.8 \\
\hline Runoff & Streamflow minus base flow & 4.9 \\
\hline $\begin{array}{l}\text { Evapotranspiration, } \\
\text { total }\end{array}$ & $\begin{array}{l}\text { Method 2: From regression model developed by Sanford and Selnick (2012) and NOAA NCDC } \\
\text { data retrieved with the GW Toolbox }\end{array}$ & 26.0 \\
\hline $\begin{array}{l}\text { Evapotranspiration, } \\
\text { groundwater }\end{array}$ & Recharge minus base flow & 3.8 \\
\hline
\end{tabular}


In some cases it is not possible to use equation 4 to estimate actual $E T$, and other approaches are needed. Sanford and Selnick (2012) developed a regression model to estimate actual ET throughout the conterminous United States on the basis of climate and land-cover data. Although the estimates of $E T$ are improved with the land-cover information, results of the Sanford and Selnick (2012) study indicate that climate variables - specifically, precipitation and temperature - are the most influential in determining ET. Because the precipitation and temperature data that are needed for the model are available with the GW Toolbox, use of the model is demonstrated here for the Pawcatuck River Basin.

The regression model is expressed as the ratio of $E T$ to $P$ in the following general form:

$$
\frac{E T}{P}=\Lambda\left(\frac{\tau \Delta}{\tau \Delta+\Pi}\right)
$$

The Greek letters reflect different nondimensional parameters: $\Lambda$ for land cover, $\tau$ for temperature, $\Delta$ for the mean diurnal temperature range, and $\Pi$ for precipitation. Variable $\Lambda$ is set equal to 1 when only climate data are used in the model. The three other variables $(\tau, \Delta$, and $\Pi)$ are defined by mathematical equations given in Sanford and Selnick (2012, table 1). In practice, the temperature and precipitation variables that are needed for the regression model and available with the GW Toolbox are: ATEM for mean annual daily temperature (variable $T_{m}$ in Sanford and Selnick, 2012, in degrees Celsius), TMAX and TMIN for mean annual maximum and minimum daily temperature (variables $T_{x}$ and $T_{n}$, in degrees Celsius), respectively; and PRCP for mean annual precipitation [variable $P$, in centimeters, $(\mathrm{cm})]$. The values of these variables for the Kingston weather station for the period from 1971 through 2000 were shown previously to be: $T_{m}=49.59^{\circ} \mathrm{F}\left(9.77^{\circ} \mathrm{C}\right), T_{x}$ $=60.73{ }^{\circ}\left(15.96^{\circ} \mathrm{C}\right), T_{n}=39.38^{\circ} \mathrm{F}\left(4.10^{\circ} \mathrm{C}\right)$, and $P=51.82$ in. $(131.62 \mathrm{~cm})$. The ratio $E T / P$ is then found from the equations presented in Sanford and Selnick (2012) to be 0.502; or, evapotranspiration was 50.2 percent of precipitation during the period from 1971 through 2000. Multiplication of $E T / P$ by the estimate of $P(51.82 \mathrm{in}$.) results in an estimated value of $E T$ of 26.0 in. for the period from 1971 through 2000. For comparison, Sanford and Selnick (2012, supplemental data table S1) estimated a value of ET/P of 48.6 percent for the entire Pawcatuck River Basin for the same period.

Three additional water-balance equations can be written for streamflow, groundwater recharge, and evapotranspiration from the water-budget components estimated previously. The first is for streamflow out of the basin:

$$
\frac{S F_{o}}{A}=\frac{B F}{A}+\frac{R O}{A}
$$

where

$B F \quad$ is the average annual rate of base flow (groundwater discharge) out of the basin (cubic length over time) and
$R O$ is the average annual rate of surface runoff to the stream (cubic length over time).

Using the mean average annual values estimated by the six hydrograph-separation methods presented earlier, base flow and surface runoff from the drainage area for the period from 1971 through 2000 are 22.8 and $4.9 \mathrm{in} / \mathrm{yr}$, respectively.

The second equation is for the average annual rate of recharge to the water table $(R$, in/yr). Following the approach suggested by Rutledge (1998, p. 39), it is assumed that the recharged water either discharges to the stream network as base flow or is lost by evapotranspiration from the groundwater system where the water table is close to land surface, such as in riparian zones:

$$
R=\frac{B F}{A}+E T_{g w}
$$

where

$$
\begin{aligned}
& E T_{\mathrm{gw}} \quad \text { is the average annual rate of } \\
& \text { evapotranspiration directly from the } \\
& \text { groundwater system, and represents an } \\
& \text { average rate distributed across the entire } \\
& \text { area of the basin (length over time). }
\end{aligned}
$$

Because the rates of recharge ( $26.6 \mathrm{in} / \mathrm{yr})$ and base flow ( $22.8 \mathrm{in} / \mathrm{yr}$ ) have been estimated from the hydrograph analyses, $E T_{g w}$ for the 30 -year period is calculated from equation 7 to be $3.8 \mathrm{in} / \mathrm{yr}$. This value is approximately 0.8 to $1.8 \mathrm{in}$. greater than those reported for the Pawcatuck River Basin by Barlow (1997) and Barlow and Dickerman (2001), most likely because the value reported here is based on six methods used to estimate base flow, whereas only the PART method was used in the analyses by Barlow (1997) and Barlow and Dickerman (2001). If only the result of the PART method is used (24.9 in/yr), a value of $E T_{g w}$ equal to $1.8 \mathrm{in} / \mathrm{yr}$ is calculated, which is within the range reported by the previous studies.

Finally, the rate of actual evapotranspiration within the basin can be broken down into two components, that from the groundwater system $\left(E T_{g w}\right)$ and the remainder from evapotranspiration near land surface and from open bodies of water $\left(E T_{n s}\right)$ :

$$
E T=E T_{n s}+E T_{g w},
$$

where

$$
\begin{aligned}
& E T_{n s} \quad \text { is the average annual rate of } \\
& \text { evapotranspiration near land surface, } \\
& \text { including open bodies of water (length } \\
& \text { over time). }
\end{aligned}
$$

Because rates of ET (24.1 in/yr) and $E T_{g w}(3.8 \mathrm{in} / \mathrm{yr})$ have been estimated previously, $E T_{n s}$ is found from equation 8 to be $20.3 \mathrm{in} / \mathrm{yr}$ for the 30 -year period. 


\section{Summary}

The primary purpose of this report is to provide a set of instructions that will allow users of the Groundwater (GW) Toolbox to quickly develop skills to use the mapping, dataretrieval, data-inspection, and hydrograph-analysis methods to estimate base flow, surface runoff, and groundwater recharge for a basin. The report describes six hydrograph-separation methods used to determine the groundwater-discharge (baseflow) and surface-runoff components of streamflow-the Base-Flow Index (BFI; Standard and Modified), HYSEP (Fixed Interval, Sliding Interval, and Local Minimum), and PART methods - and the RORA recession-curve displacement method and associated RECESS method to estimate groundwater recharge from streamflow data. The GW Toolbox provides graphing, mapping, and analysis capabilities using a geographic information system driver within a Microsoft Windows environment. The GW Toolbox contains several preprocessed GIS data layers, meteorological data from the National Oceanic and Atmospheric Administration National Climatic Data Center, and automated tools to retrieve time-series data from NWIS.

Each of the hydrograph-analysis methods is based on a number of simplifying assumptions that limit their applicability. The methods should be applied to the analysis of streamflow hydrographs that reflect contributions from two sources: surface runoff in response to a precipitation event and groundwater discharge from a single aquifer. The methods are intended for application to basins dominated by diffuse areal groundwater recharge uniformly distributed over a basin, as opposed to focused groundwater recharge such as occurs from losing stream reaches. All groundwater recharge within the basin discharges to the receiving stream network except that amount that is evapotranspired directly from the groundwater system (sometimes referred to as riparian evapotranspiration). These hydrograph-separation methods are based on the assumption that groundwater discharge to streams is a continuous process, whereas the recession-curve displacement method is based on the assumption of episodic recharge in response to storms. Figure 1 in the report provides guidance on the appropriateness of hydrograph-analysis methods provided with the GW Toolbox for application to a particular basin. Users should understand the hydrologic conditions in a basin to confirm the quantitative results of the hydrograph-analysis methods. Execution of multiple hydrograph-analysis methods simultaneously helps the user to frame the range of base flow and recharge estimates.

The methods provided with this version of the GW Toolbox are demonstrated with streamflow data collected at the Pawcatuck River at Wood River Junction, Rhode Island, streamgage. Using the data-retrieval and data-analysis tools within the GW Toolbox, the report provides a tutorial of the steps necessary to estimate many of the components of the water budget for a hydrologic basin, including precipitation; streamflow; base flow; runoff; groundwater recharge; and total, groundwater, and near-surface evapotranspiration.

\section{References Cited}

Arnold, J.G., and Allen, P.M., 1999, Automated methods for estimating baseflow and ground water recharge from streamflow records: Journal of the American Water Resources Association, v. 35, no. 2, p. 411-424.

Barlow, P.M., 1997, Dynamic models for conjunctive management of stream-aquifer systems of the glaciated northeast: Storrs, Conn., University of Connecticut, Ph.D. dissertation, $256 \mathrm{p}$.

Barlow, P.M., and Dickerman, D.C., 2001, Numerical-simulation and conjunctive-management models of the HuntAnnaquatucket-Pettaquamscutt stream-aquifer system, Rhode Island: U.S. Geological Survey Professional Paper 1636, 88 p., http://pubs.usgs.gov/pp/pp1636/.

Bent, G.C., Zarriello, P.J., Granato, G.E., Masterson, J.P., Walter, D.A., Waite, A.M., and Church, P.E., 2011, Simulated effects of water withdrawals and land-use changes on streamflows and groundwater levels in the Pawcatuck River Basin, southwestern Rhode Island and southeastern Connecticut: U.S. Geological Survey Scientific Investigations Report 2009-5127, 254 p., http: //pubs.usgs.gov/ $\operatorname{sir} / 2009 / 5127 /$.

Cervione, M.A., Jr., Richardson, A.R., and Weiss, L.A., 1993, Low-flow characteristics of selected streams in Rhode Island: U.S. Geological Survey Water-Resources Investigations Report 93-4046, 16 p., http://pubs.er.usgs.gov/publication/wri934046.

Delin, G.N., Healy, R.W., Lorenz, D.L., and Nimmo, J.R., 2007, Comparison of local- to regional-scale estimates of ground-water recharge in Minnesota, USA: Journal of Hydrology, v. 334, nos. 1-2, p. 231-249.

Eckhardt, K., 2005, How to construct recursive digital filters for baseflow separation: Hydrological Processes, v. 19, p. 507-515.

Eddy-Miller, C.A., Constantz, Jim, Wheeler, J.D., Caldwell, R.R., and Barlow, J.R.B., 2012, Demonstrating usefulness of real-time monitoring at streambank wells coupled with active streamgages - Pilot studies in Wyoming, Montana, and Mississippi: U.S. Geological Survey Fact Sheet 2012-3054, 6 p., http://pubs.usgs.gov/fs/2012/3054/.

Halford, K.J., 2008, Discussion on "Update on the use of the RORA program for recharge estimation," by Al Rutledge: Ground Water, v. 46, no. 1, p. 10-11.

Halford, K.J., and Mayer, G.C., 2000, Problems associated with estimating ground water discharge and recharge from stream-discharge records: Ground Water, v. 38, no. 3, p. 331-342. 
Hamon, W.R., 1961, Estimating potential evapotranspiration: Journal of the Hydraulics Division, Proceedings of the American Society of Civil Engineers, v. 87, no. HY3, p. $107-120$.

Healy, R.W., 2010, Estimating groundwater recharge: Cambridge, United Kingdom, Cambridge University Press, $245 \mathrm{p}$.

Healy, R.W., Winter, T.C., LaBaugh, J.W., and Franke, O.L., 2007, Water budgets - Foundations for effective waterresources and environmental management: U.S. Geological Survey Circular 1308, 90 p., http://pubs.usgs.gov/ circ/2007/1308/.

Institute of Hydrology, 1980a, Research report, v. 1 of Low flow studies: Wallingford, United Kingdom, Institute of Hydrology, 42 p.

Institute of Hydrology, 1980b, Catchment characteristic estimation manual, v. 3 of Low flow studies: Wallingford, United Kingdom, Institute of Hydrology, 27 p.

Lim, K.J., Engel, B.A., Zhenxu, Tang, Choi, Joongdae, Kim, K.S., Muthukrishnan, Suresh, and Tripathy, Dibyajyoti, 2005, Automated WEB GIS based hydrograph analysis tool, WHAT: Journal of the American Water Resources Association, v. 41, no. 6, p. 1407-1416.

MapWindow, 2013, MapWindow GIS Open Source Project: MapWindow Web site, accessed December 13, 2013, at http://www.mapwindow.org/.

Nathan, R.J., and McMahon, 1990, Evaluation of automated techniques for base flow and recession analyses: Water Resources Research, v. 26, no. 7, p. 1465-1473.

Pettyjohn, W.A., and Henning, Roger, 1979, Preliminary estimate of ground-water recharge rates, related streamflow and water quality in Ohio: Columbus, Ohio State University, Water Resources Center Project Completion Report 552, $323 \mathrm{p}$.

Piggott, A.R., Moin, Syed, and Southam, Chuck, 2005, A revised approach to the UKIH method for the calculation of baseflow: Hydrological Sciences, v. 50, no. 5, p. 911-920.

Risser, D.W., Gburek, W.J., and Folmar, G.J., 2005, Comparison of methods for estimating ground-water recharge and base flow at a small watershed underlain by fractured bedrock in the eastern United States: U.S. Geological Survey Scientific Investigations Report 2005-5038, 31 p.

Rorabaugh, M.I., 1964, Estimating changes in bank storage and ground-water contribution to streamflow: International Association of Scientific Hydrology Publication 63, p. 432-441.
Rosenberry, D.O., and LaBaugh, J.W., 2008, Field techniques for estimating water fluxes between surface water and ground water: U.S. Geological Survey Techniques and Methods, book 4, chap. D2, 128 p., http://pubs.usgs.gov/ tm/04d02/.

Rutledge, A.T., 2007, Update on the use of the RORA program for recharge estimation: Ground Water, v. 45 , no. 3 , p. 374-382.

Rutledge, A.T., 1998, Computer programs for describing the recession of ground-water discharge and for estimating mean ground-water recharge and discharge from streamflow records-Update: U.S. Geological Survey Water-Resources Investigations Report 98-4148, 43 p., http://pubs.usgs.gov/ wri/wri984148/.

Rutledge, A.T., 2000, Considerations for use of the RORA program to estimate ground-water recharge from streamflow records: U.S. Geological Survey Open-File Report 2000156, 44 p., http://pubs.usgs.gov/of/2000/ofr00-156/.

Rutledge, A.T., and Daniel, C.C., III, 1994, Testing an automated method to estimate ground-water recharge from streamflow records: Ground Water, v. 32, no. 2, p. 180-189.

Rutledge, A.T., and Mesko, T.O., 1996, Estimated hydrologic characteristics of shallow aquifer systems in the Valley and Ridge, the Blue Ridge, and the Piedmont Physiographic Provinces based on analysis of streamflow recession and base flow: U.S. Geological Survey Professional Paper 1422-B, 58 p.

Sanford, W.E., Nelms, D.L., Pope, J.P., and Selnick, D.L., 2012, Quantifying components of the hydrologic cycle in Virginia using chemical hydrograph separation and multiple regression analysis: U.S. Geological Survey Scientific Investigations Report 2011-5198, 152 p., http://pubs.usgs. gov/sir/2011/5198/.

Sanford, W.E., and Selnick, D.L., 2012, Estimation of evapotranspiration across the conterminous United States using a regression with climate and land-cover data: Journal of the American Water Resources Association, v. 49, issue 1, p. 217-230, http://dx.doi.org/10.1111/jawr.12010.

Seaber, P.R., Kapinos, F.P., and Knapp, G.L., 1987, Hydrologic unit maps: U.S. Geological Survey Water-Supply Paper 2294, 63 p., http://pubs.usgs.gov/wsp/wsp2294/.

Sloto, R.A., and Crouse, M.Y., 1996, HYSEP-A computer program for streamflow hydrograph separation and analysis: U.S. Geological Survey Water-Resources Investigations Report 96-4040, 46 p., http://pubs.er.usgs.gov/publication/ wri964040. 
Stonestrom, D.A., and Constantz, Jim, eds., 2003, Heat as a tool for studying the movement of ground water near streams: U.S. Geological Survey Circular 1260, 96 p., http://pubs.usgs.gov/circ/2003/circ1260/.

U.S. Environmental Protection Agency, 2013, BASINS (better assessment science integrating point and non-point sources): U.S. Environmental Protection Agency Web site, accessed December 13, 2013, at http://water.epa.gov/scitech/datait/ models/basins/index.cfm.

U.S. Geological Survey, 2013, Web interface: U.S. Geological Survey National Water Information System Web site, accessed December 13, 2013, at http://waterdata.usgs.gov/ nwis/.

Wahl, K.L., and Wahl, T.L., 1995, Determining the flow of Comal Springs at New Braunfels, Texas, in Proceedings of Texas Water 95, August 16-17, 1995, San Antonio, Tex.: American Society of Civil Engineers, p. 77-86. 

Prepared by the Pembroke Publishing Service Center.

For more information concerning this report, contact:

Chief

Office of Groundwater

U.S. Geological Survey

411 Federal Center

Reston, VA 20192

http://water.usgs.gov/ogw 


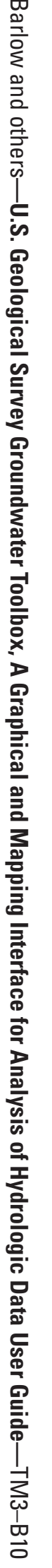

